\title{
Conversando com meu Eu do passado
}

ORGANIZAÇÃO

LUCIANE RIBEIRO DIAS GONÇALVES
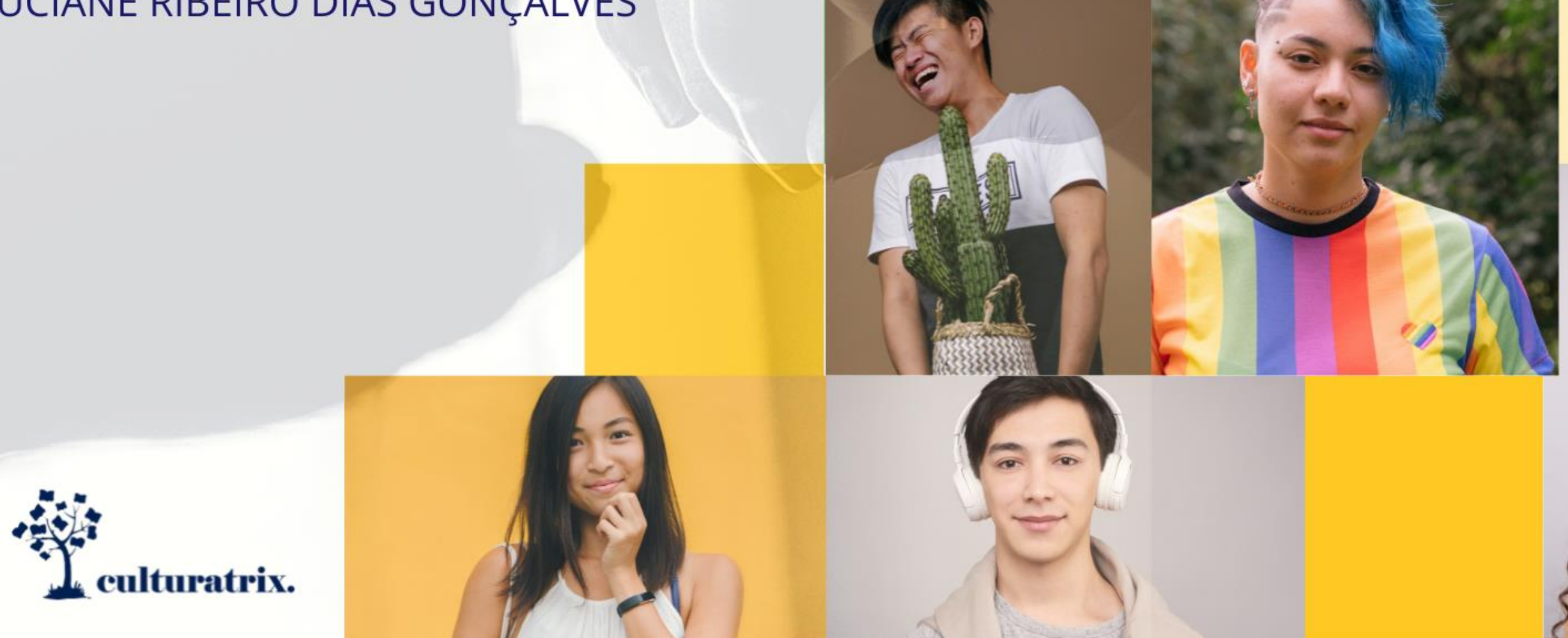
Conversando com meu Eu do passado 


\section{Editora culturatrix.}

| publicações acadêmicas |

Editora chefe

Rosa Maria Ferreira da Silva
Editor assistente

Cairo Mohamad Ibrahim Katrib (UFU)

\section{conselho Editorial - Consultivo}

Altina Abadia da Silva (UFCAT)

Eliane Martins de Freitas (UFCAT)

Emília Saraiva Nery (FACEMA)

Euclides Antunes de Medeiros (UFT)

Floriana Rosa da Silva (SRE-MG)

Iara Toscano Correia (UFU)

Helena Maria Ferreira (UFLA)

Luís André Nepomuceno (UNIPAM)

Marcos Antônio de Menezes (UFG)
Miguel Rodrigues de Sousa Neto (UFMS)

Olívia Cormineiro (UFT)

Regma Maria dos Santos (UFCAT)

Remi Castioni (UnB)

Renato Jales Silva Júnior (UFMS)

Ricardo Vidal Golovaty (IFG)

Sandro Prado Santos (UFU)

Simone Aparecida dos Passos (UFU)

Tadeu Pereira dos Santos (UNIR) 


\section{Conversando com meu Eu do passado}

ORGANIZAÇÃO

LUCIANE RIBEIRO DIAS GONÇALVES

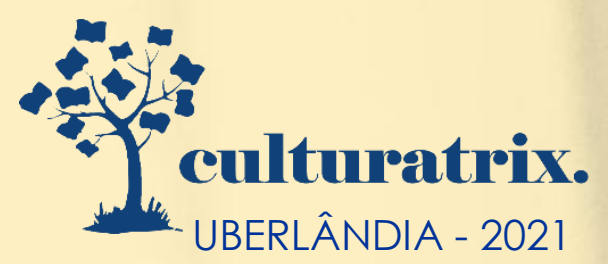


Copyright 2021 @ L Luciane Ribeiro Dias Gonçalves, 2021.

Todos os direitos reservados

Editora de Publicação: Rosa Maria Ferreira da Silva

Projeto Gráfico e diagramação: Studio Escrita \& Criação

Imagens de capa e miolo: Jenna Hamra e Canva Pictures Free

Conversando com meu eu do passado / Organização de Luciane Ribeiro Dias Gonçalves. - Uberlândia-MG:

Culturatrix, 2021

\author{
Livro Digital \\ Extensão: PDF \\ Acesso: Internet
}

50 p., II.

SBN: 978-65-86889-14-7

DOI: 10.4322/978-65-86889-14-

1. Estágio Supervisionado. 2. Educação de Jovens e Adultos.

3. Pandemia. 4. Curso de Pedagogia - UFU I. Ribeiro Dias Gonçalves, Luciane (Organizadora). II. Título.

CDD 370.71

Editora Culturatrix

Rua Nordau Gonçalves de Mello, 1116, Santa Mônica | CEP: 38408218. Uberlândia, MG. Tel. (34) 3477 0860/ Cel./WhatsApp: (34) 997668930

CNPJ: 26896 970/0001-00

www.culturatrix.com |contato.culturatrix@gmail.com
Índice para catálogo sistemático

I. Atividade de Estágio Supervisionado 
Olá leitor/a,

Você já imaginou a possibilidade de conversar com seu EU do passado? Foi essa experiência que fizemos como forma de acolhimento das -disciplinas Prointer III, Educação de Jovens e Adultos e Estágio Supervisionado Iem Espaço Não Escolar do Curso de Pedagogia, da Universidade Federal de Uberlândia, Campus Pontal, onde ministrei aulas no primeiro semestre de 2021.

Esta atividade foi inspirada em um vídeo de Franklin Medrado. A partir dele, foi só colocar nossa criatividade em ação. Conversamos com nós mesmos/as e nos enviamos vários recadinhos. Entendemos que, mesmo no il sofrimento do momento pandêmico, podemos colher histórias que servirão dè inspiração para cada um de nós.

Dedicamos essa nossa escrita a todos/as que foram afetados/as, perderam um ente querido na pandemia e/ou ficaram emocionalmente abalados/as. Estamos aqui nos reconstruindo e nos abraçando de forma virtual.

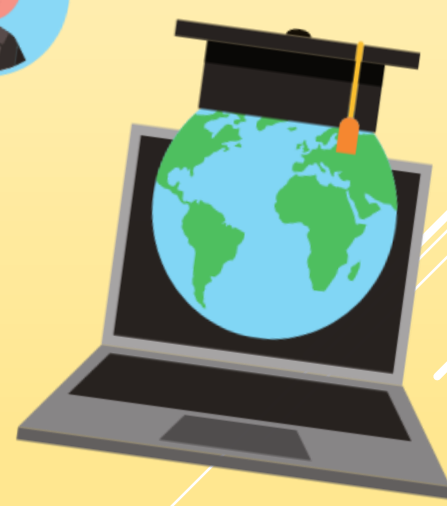
sintam nosso abraço.

Prof ${ }^{a}$ Luciane Dias Pedagogia/ICHPO/UFU 
Olá, Tauane Resende Luisa de Oliveria, sou o seu eu do futuro. Queria lhe dizer que ess ano a Sara não vai para a escolinha. Você vai conseguir entrar no PIBID, mas não vai nada de ir para a escola, fazer atividades com as crianças, nada disso. Se for comprar roupa, pode escolher um tamanho maior, por que esse ano vamos engordar uns quilinhos [risos]. Aproveite os momentos na terapia e não se desespere, vai ficar tudo bem.
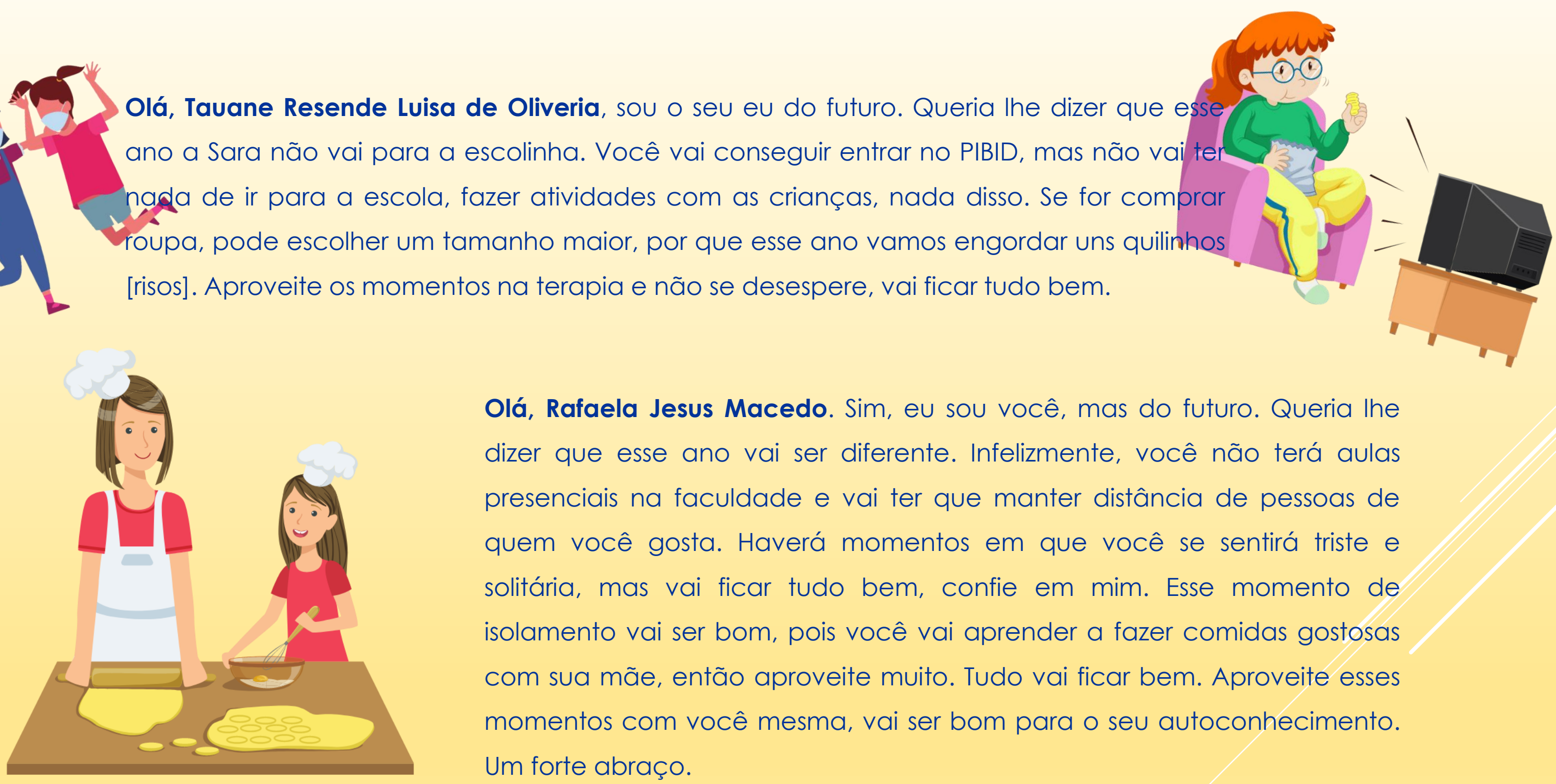

Olá, Rafaela Jesus Macedo. Sim, eu sou você, mas do futuro. Queria lhe dizer que esse ano vai ser diferente. Infelizmente, você não terá aulas presenciais na faculdade e vai ter que manter distância de pessoas de quem você gosta. Haverá momentos em que você se sentirá triste e solitária, mas vai ficar tudo bem, confie em mim. Esse momento de isolamento vai ser bom, pois você vai aprender a fazer comidas gostosas com sua mãe, então aproveite muito. Tudo vai ficar bem. Aproveite esses momentos com você mesma, vai ser bom para o seu autoconhecimento. Um forte abraço. 
Oi, Amanda Alves Muniz, eu sou você no futuro. Então... esse ano você vai ficar um bom tempo sem ir para faculdade. Sabe aquilo que você falava no fim do semestre, quando as coisas estavam difíceis, que as férias podiam durar do meio do ano até dezembro? Pois é, isso quase se tornou real. Não brinque mais com coisa séria [risos]... Às vezes, você sentirá muita vontade de sair de casa e passe mas evite isso, por enquanto. Aproveite o tempo livre para arrumar a bagunça do seu quarto! Beijos e fique bem. Quando as aulas presenciais voltarem, não se desespere... no fim, deu tudo certo!

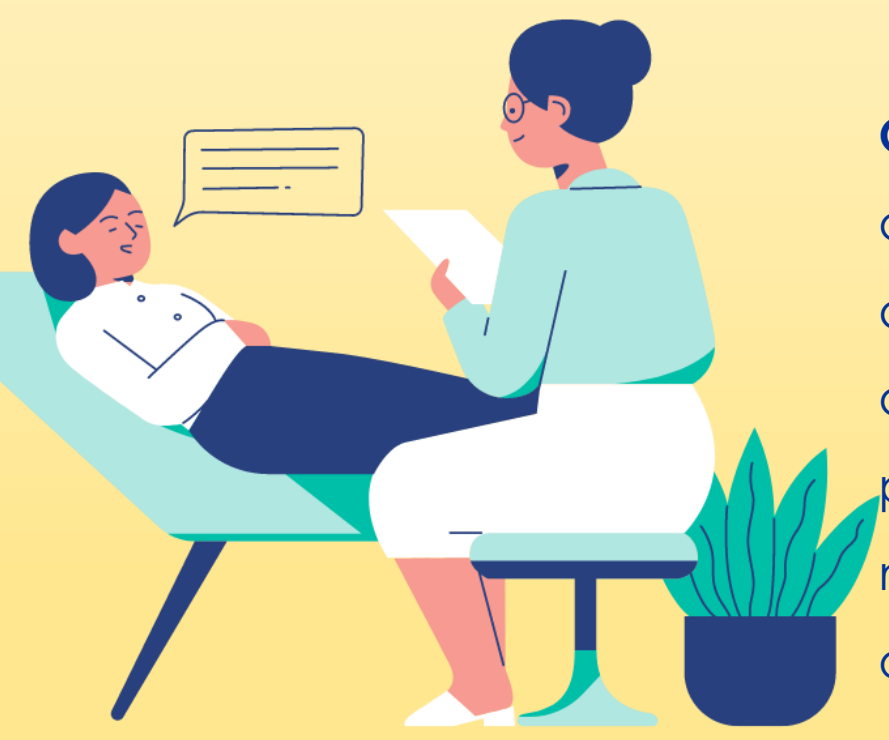

Olá, Polly Ana Rodrigues Ferreira. Como você se sente hoje? Queria the dizer que esse ano não vai ser fácil! A gente está vivendo uma pandemia e apesar da sua expectativa de voltar para a faculdade (presencialmente), isso vai demorar um pouquinho [risos]. Você precisou voltar para a terapia e, no processo, desconstruiu, construiu e reconstruiu várias coisas. Espero que você

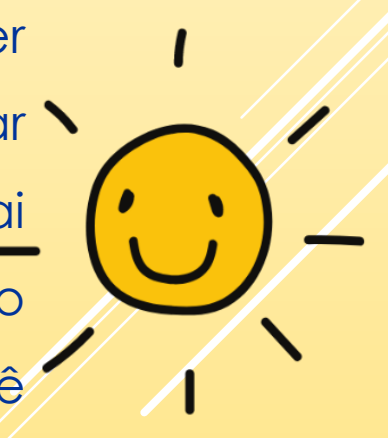
nunca se esqueça que o sol nasce todo dia... e a gente sempre tem a oportunidade de recomeçar. Se orgulhe de quem você é. Com amor... Polly. 


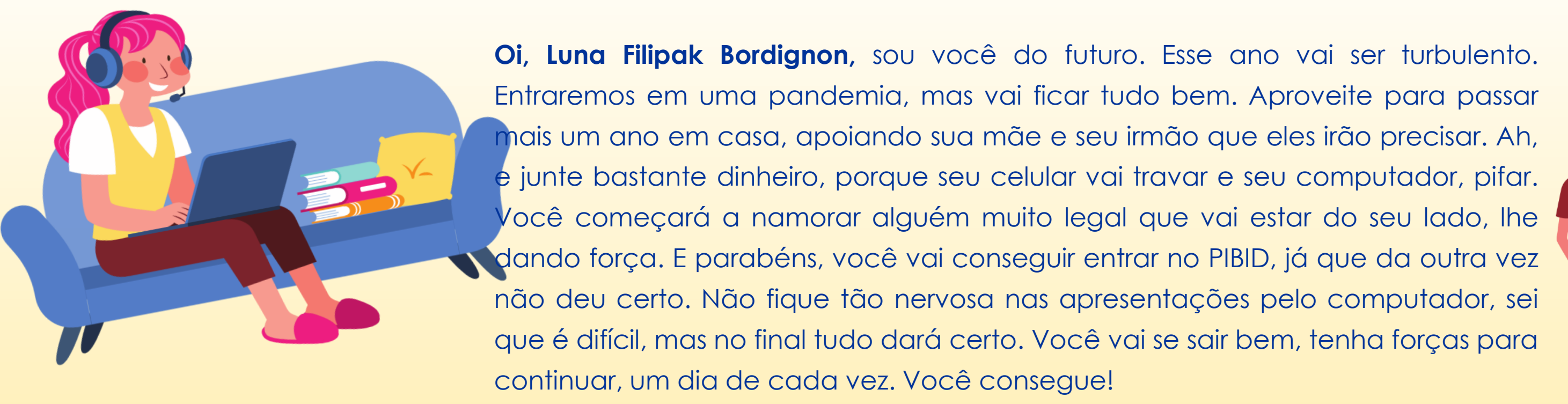
Oi, Luna Filipak Bordignon, sou você do futuro. Esse ano vai ser turbulento. Entraremos em uma pandemia, mas vai ficar tudo bem. Aproveite para passar mais um ano em casa, apoiando sua mãe e seu irmão que eles irão precisar. Ah, e junte bastante dinheiro, porque seu celular vai travar e seu computador, pifar. Você começará a namorar alguém muito legal que vai estar do seu lado, Ihe não deu certo. Não fique tão nervosa nas apresentações pelo computador, sei que é difícil, mas no final tudo dará certo. Você vai se sair bem, tenha forças para continuar, um dia de cada vez. Você consegue!

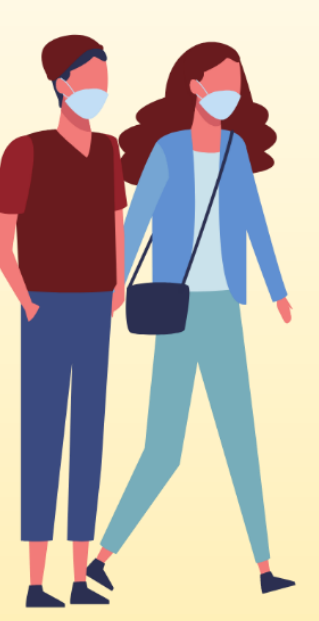

Olá, Amanda Matias de Souza, sou você no futuro. Quero que saiba que, por mais difícil que seja, não desista. Tudo tem seu tempo, se esforce cada dia mais para quando olhar para trás você veja o que conseguiu conquistar. Esse tempo de pandemia que estamos vivendo será difícil para todos nós. Aguardamos a vacina para que, assim, possamos voltar às nossas rotinas de aulas presenciais.... Então, por ora, aproveite bem aulas a distância para conhecer um pouco de seus

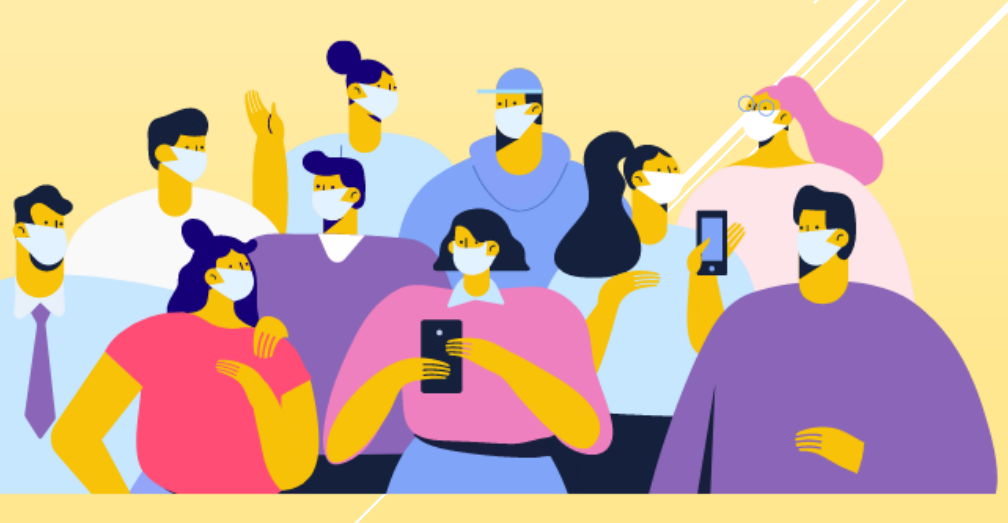
colegas e professores/as, quebre essa vergonha, menina, e vida que segue!!! 
Oi, Raquel de Souza Oliveira, você vai viver um ano tão diferente, de um jeito que você nunca imaginou. Mas, vai ser um ano em que você e sua família vão realizar sonhos também e serem surpreendidos com coisas que desejaram por muito tempo... Esse ano vai acontecer... Então continue na fé, que tudo vai dar certo. Até breve.

Leonardo Araujo Borges. Leo, ô Leo... Brasil tá lascado e eu vim the avisar que vai piorar. Você terá algumas expectativas quebradas, principalmente a respeito da universidade, mas coisas boas também irão acontecer. Até porque você estará mais entendido e envolvido com o curso. Com a determinação que sempre lhe moveu, você irá continuar os estudos e ainda terá boas oportunidades nesse itinerário [risos]. Ficará viciadão em BBB e prepare-se para ficar chocado com os acontecimentos. Não se esqueça do arroz no fogo e tenha mais paciência, pois vai precisar. Se tudo estiver difícil, tome um vinho e bote marrom. Ah, detalhezinho: carnaval em Salvador vai ter que esperar um cadim.

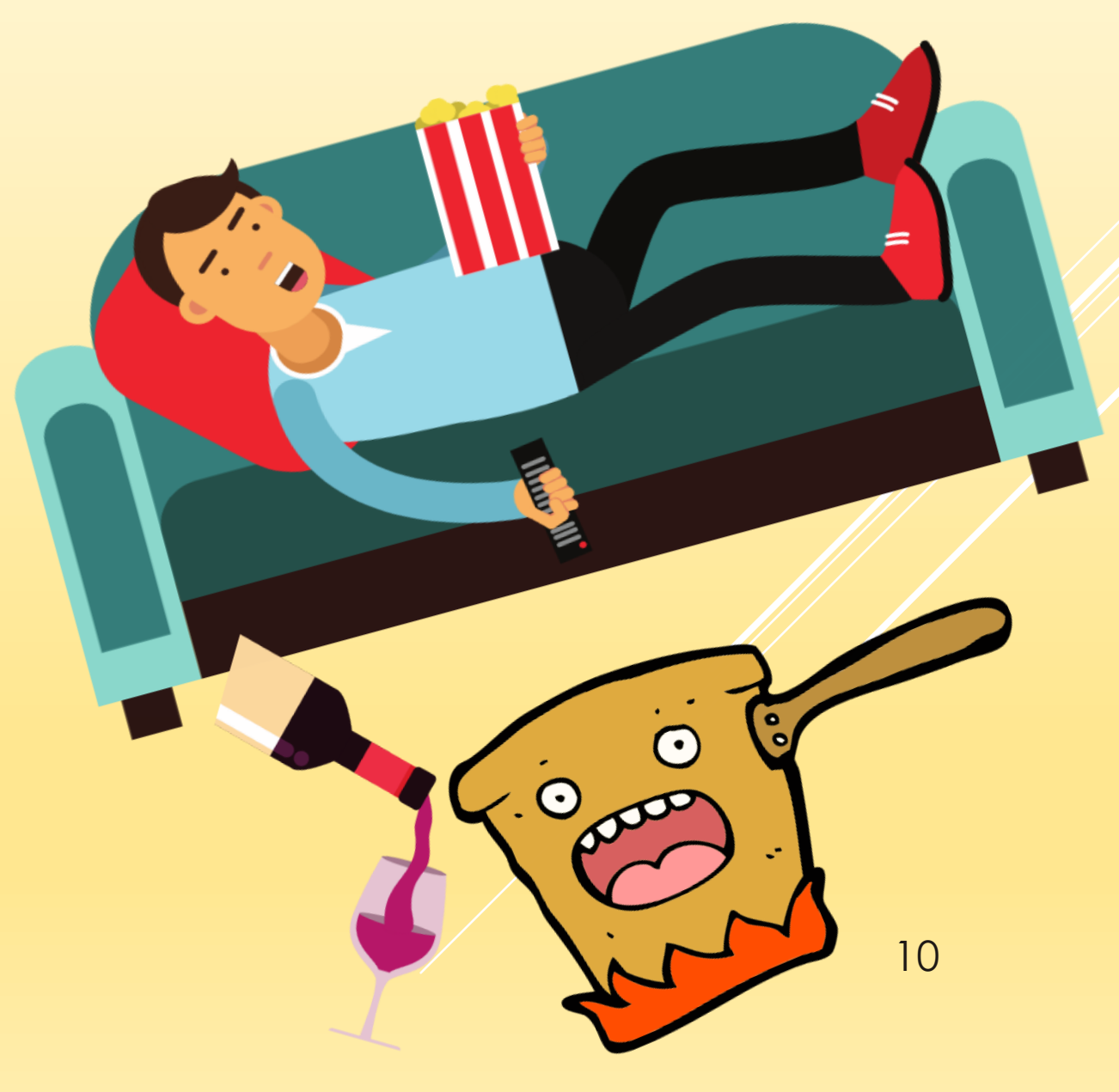


Olá, Thayanne Rhayanne Freitas Modesto. Bom dia, sou a Thayanne do futuro, esse ano será um ano de mudanças. Sim... você irá estudar no período integral, entrar no PIBID, viver um distanciamento social, mas irá dar tudo certo. Tenha esperança e fé em Deus, pois tudo vai ficar bem. Abraço afetuoso.

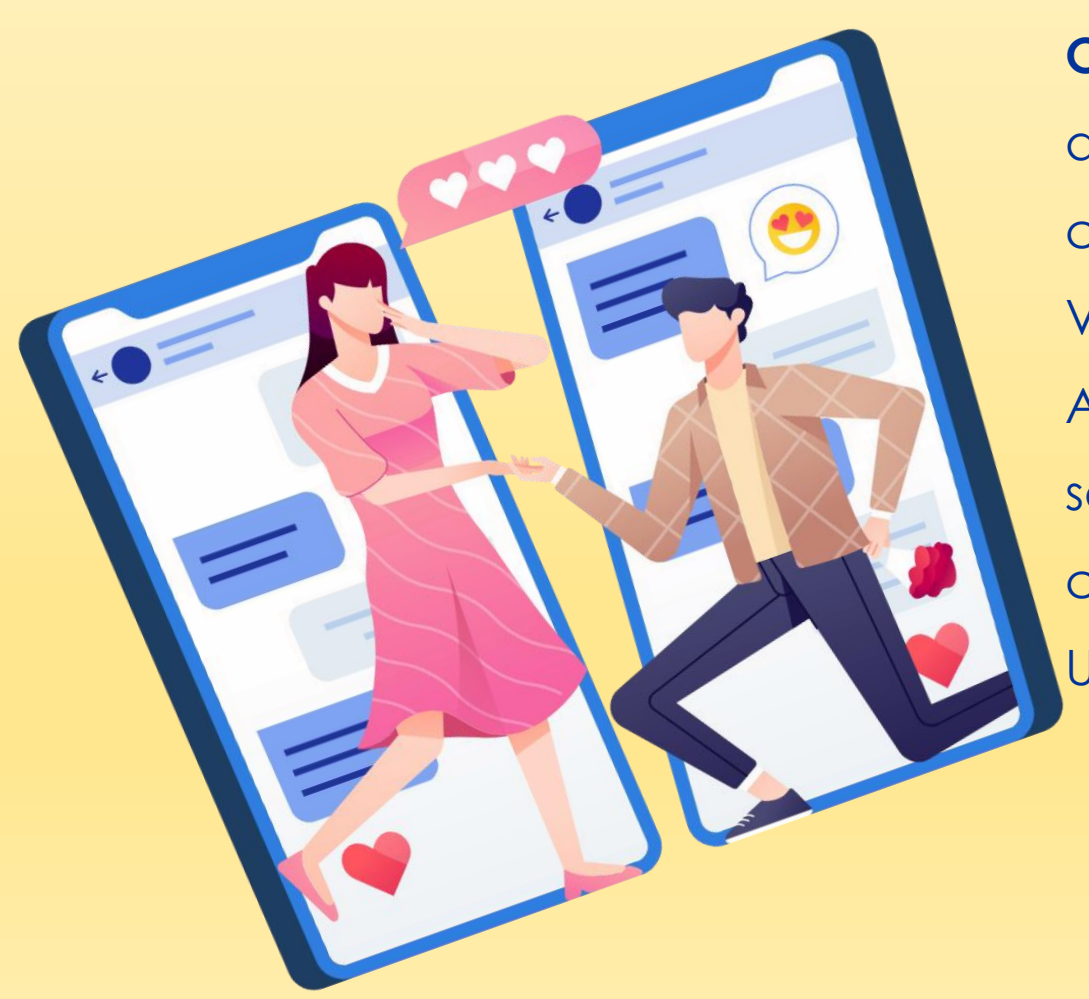

Olá, Jennifer Florindo de Aguiar. Tudo bem com você? Quero lhe dizer que esse ano não vai ser fácil. Vamos entrar em uma pandemia. Não se desespere e se cuide sempre. E jamais se esqueça do seu potencial e o quão incrivel você é. Vamos enfrentar um relacionamento a distância, mas você vão ficar bem viu? Aproveite cada momento e oportunidade... Diga para as pessoas o que você sente, demonstre sempre amor, gentileza e compaixão com todos que a cercam. Ah, pratiquei sempre o autocuidado e faça bastante cházin o alecrim. Um cheiro, Jennifer.

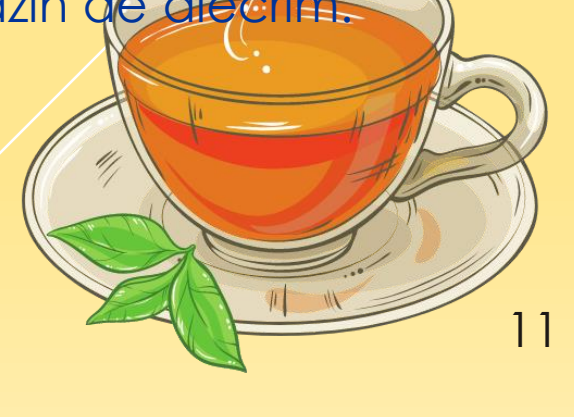


Oi, Maria Eduarda Santos Teixeira Duarte, sou você do futuro. Esse ano não tem sido fácil, né? Você vivenciou momentos jamais imaginados... Houve perdas, mas também alegrias e bastante aprendizado. Nessa pandemia, tenha bastante calma que tudo vai passar, aproveite sua família, acredite mais em você... Tudo dará certo.

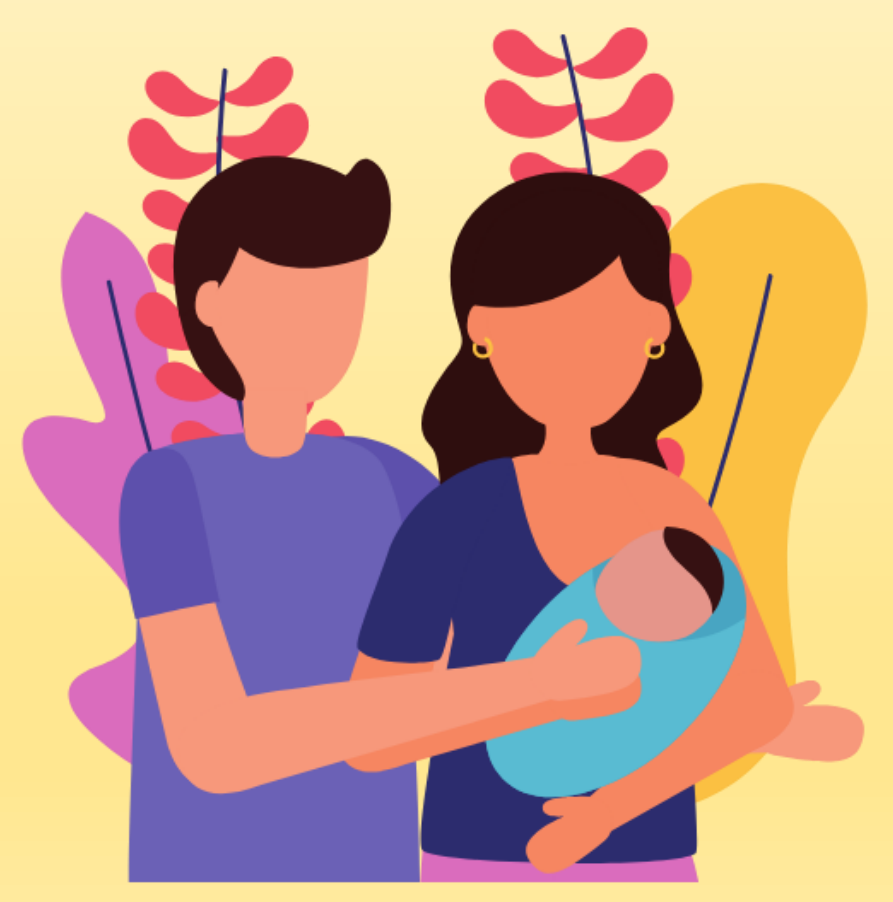

Olá, Mariana Souza Santos. Foram criadas expectativas enormes para o novo ano. Um novo ciclo de vida com o casamento, a maternidade e em como seria lidar com tudo isso conjuntamente com os estudos e consigo mesma... Relembrando isso, vem uma nostalgia, saudade de momentos... Fique bem... 


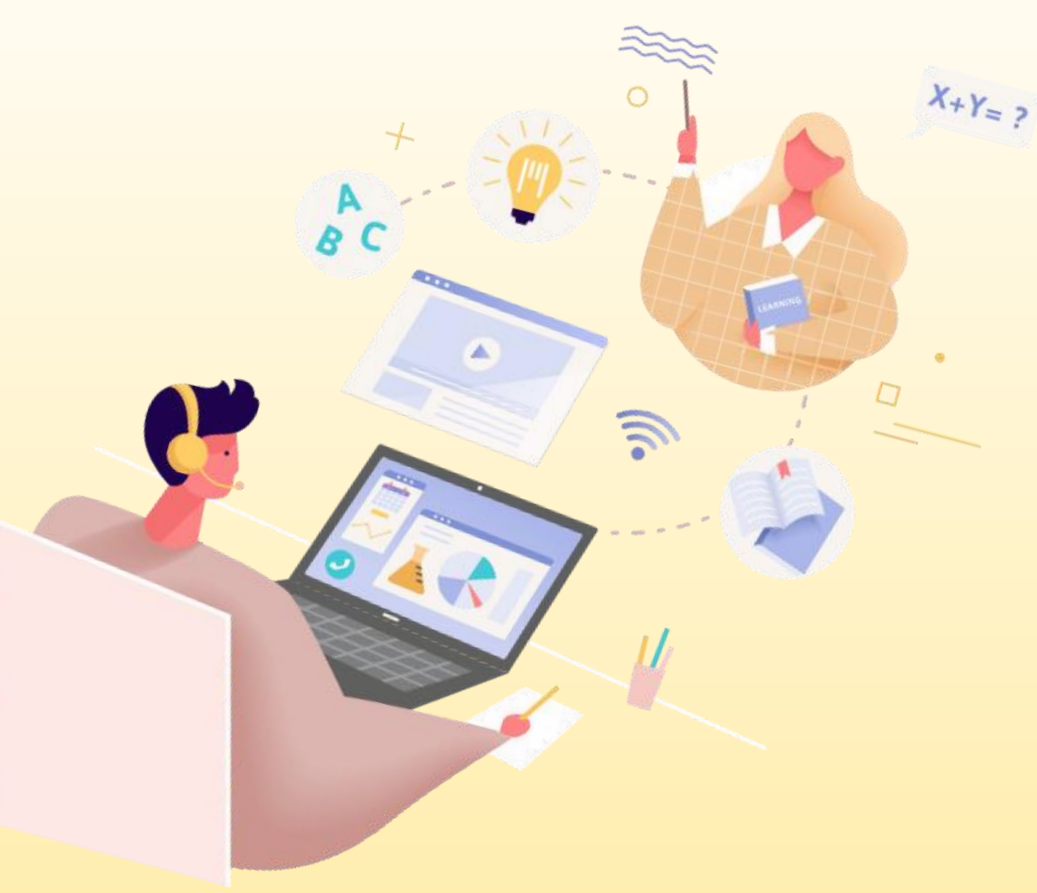

Início de 2020, eu, Edineia Etelvina de Morais, comemorei a chegada do ano novo cheias de expectativas na vida pessoal e acadêmica. Mas, a pandemia chegou e se instalou. Tive que me adaptar às aulas remotas, estudar de casa. Apesar das dificuldades, com o decorrer das aulas consegui superar obstáculos. Que nesse 2021, Deus abençoe todas nós nessa nova jornada.

Oi, Marianne Cintra de Souza Alves, sou você do futuro. Esse ano não será nada fácil. Você terá que se adaptar a várias mudanças na sua vida, principalmente em relação à faculdade. Você passará muito tempo em casa. Lembra de quando levantava desanimada para ir a faculdade e pensava "nossa, hoje poderia não ter aula!" Pois é, agora você terá saudades da faculdade. Saiba que mesmo com as dificuldades das aulas remotas, será um grande. Você irá ingressar no Pibid, porém on-line. Aproveite esse momento em casa para curtir mais o Lorenzo... Ah, cobre-se menos, pois você não precisa dar conta de tudo sempre!!! Acredite e tudo dará certo... Beijinho.

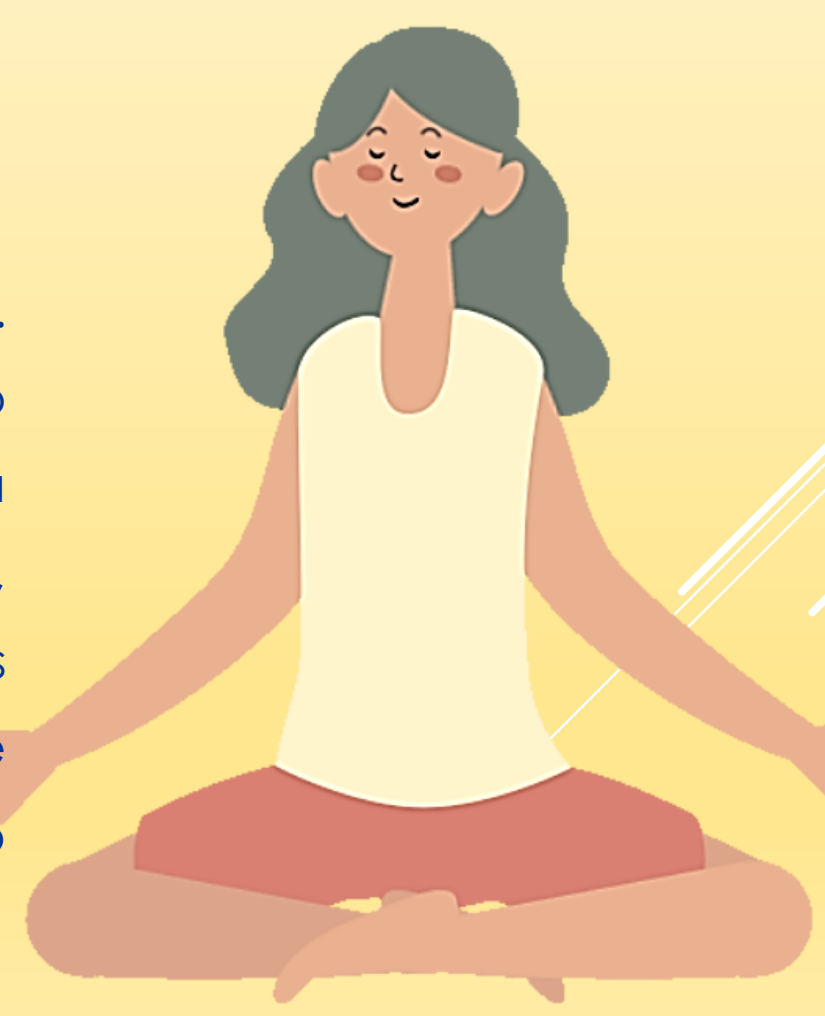




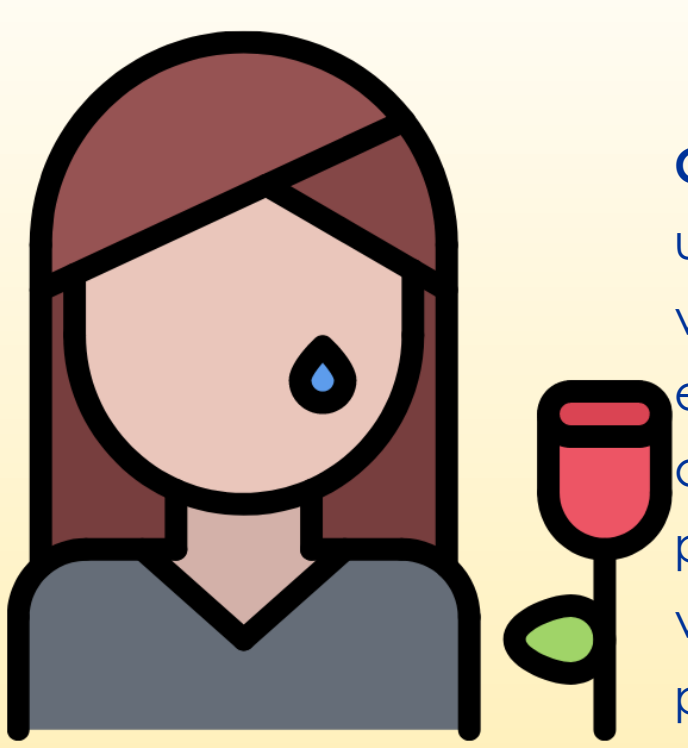

Como vai, Charlene Cristiane Medeiros de Moura? Bem, como começar uma carta para mim mesma? E o pior é tendo que dar notícias ruins que vão the ferir profundamente. Eu sou você do futuro. Estou em 2021, exatamente no dia 3 de março, praticamente no mesmo mês em que decidimos trabalhar com nossas decorações por conta própria. A propósito, sobre essa questão, foi uma ótima ideia. Hoje, em 2021, temos várias clientes e estamos conseguindo caminhar. Por outro lado perdemos duas pessoas muito importantes: a mamãe faleceu com covid 19 em setembro e o Roberto, esposo dela, também. Infelizmente eles não resistiram a essa doença que está atacando o mundo inteiro. Milhares de pessoas já morreram e ainda estão morrendo. Nossa cidade Ituiutaba, está em colapso. Tudo praticamente está fechado: comércios, academias, salões de festa, isso para tentar reduzir o contágio. No ano de 2020, vamos estudar os dois semestre por acesso remoto, tudo on-line. Será um desafio, mas nós topamos tudo. Então, minha linda, abrace mais, ame mais, perdoe mais. Só que vai doer muito no final de tudo.

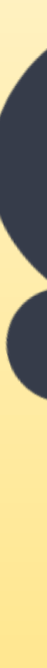

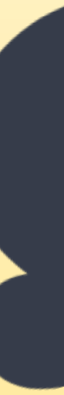
(9)

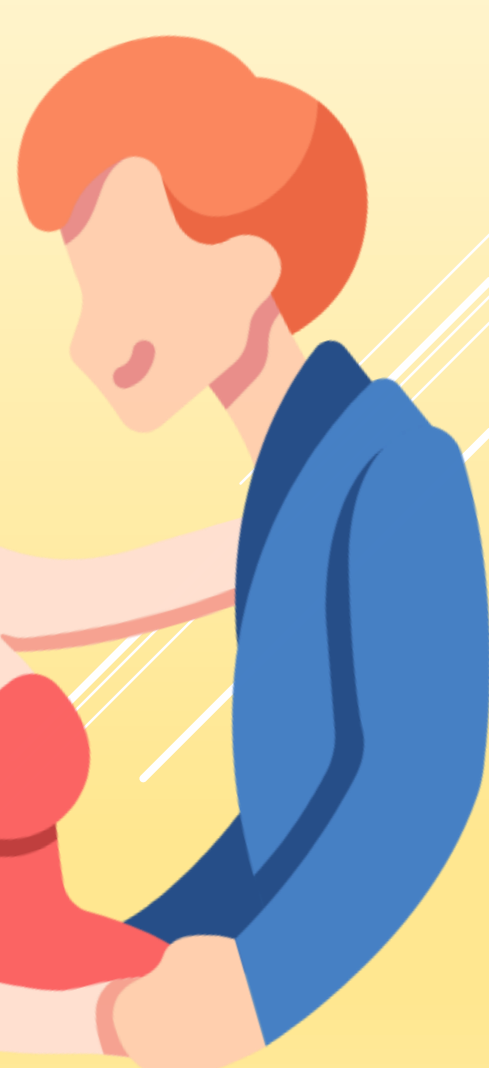


Oi, Camilla Soares Scardasi. Eu sei que está tudo muito bem, que as coisas parecem estar ótimas tanto para você quanto para o restante do mundo, mas tenho que lhe dizer que, nesse ano que está por vir, muita coisa vai acontecer. Senta que o baque vai ser forte... Mas, calma... Eu nem falei o porquê estou aqui lhe contando isso. Eu sou você do futuro. Quero lhe contar que nesse um ano que passou o mundo inteiro se transformou. Pessoas revelaram suas piores versões e uma grande doença chamada Corona Vírus acometeu milhares de pessoas. Muitas não conseguiram sobreviver, outras ficaram com sequelas. Além disso, o vírus que acometeu mundialmente muitas pessoas, abalou não só a saúde mas a estrutura social de emprego e educação que já não era das melhores. Muita gente ficou desempregada; outras não tiveram escolha: ou iam trabalhar ou eram demitidas, pessoas que necessitavam de salário para sustentar outras vidas; moradores de rua, que já vivem uma condição de vida vulnerável, ficaram ainda mais vulneráveis; mulheres que sofrem diariamente abusos psicológicos e físicos em seus lares ficaram mais suscetíveis à violência... A chegada do vírus e, consequentemente, da quarentena só deixou mais evidente parcelas que se encontram à margem da sociedade. A educação também foi abalada, professores e alunos tiveram que se readaptar a um novo formato de "sala de aula", e a parte da gestão escolar ficou completamente sobrecarregada. Foi um período de muita dor e adaptação para o mundo inteiro. Mas, e você? Como ficou nesse tempo? Muitas coisas às quais esperava que fossem acontecer não aconteceram, assim como momentos que você achou que não viveria tão cedo e acabou vivendo. Apesar da quarentena ter sido ruim e ainda permanecer, ela trouxe a oportunidade de você ficar mais na sua casa com sua família. Foram novos desafios, quais você nem imaginaria passar... Eu só quero dizer para você aproveitar o carnaval abraçar todas as pessoas do mundo até as desconhecidas, pois não poderá tão cedo. Tenha paciência com você e com o seu período de transformaçãd adaptação e acredite: você é forte e vai longe e onde quiser. 
Tudo bem, Vitória Faion Steter? Quem diria que todo o roteiro que você programou para realizar iria, de repente, mudar o percurso, sem ninguém prever, sem ninguém ao menos esperar e se preparar. Aconteceu do nada, sem que ao menos você pudesse sentir a mudança, mas lembre-se de uma coisa: mudança para você sempre foi sinônimo de aprendizado. Todas as suas mudanças foram doloridas, angustiantes, e muitas você até pensou "porque eu tenho que passar por isso", e no final você sempre passou e aprendeu muito, então eu digo para que você não se apavore durante o seu próximo destino, não perca o controle, e nem a fé, você não está onde queria, mas onde deveria. Se eu te contasse que tudo isso aconteceria você nem ia acreditar, née Seu sofrimento em JANEIRO por não poder comemorar o seu aniversário em AGOSTO, por estar em uma cidade distante e com pessoas conhecidas, você lembra disso? Fazer planos para o futuro é bom sim, mas um ensinamento que eu quero ressaltar para você é: viva sempre o presente, o passado já foi e o futuro pode ser que nem venha, ou que, mude o percurso. Aproveite o máximo e da melhor maneira possível, faça o melhor que você pode, agora, no presente.

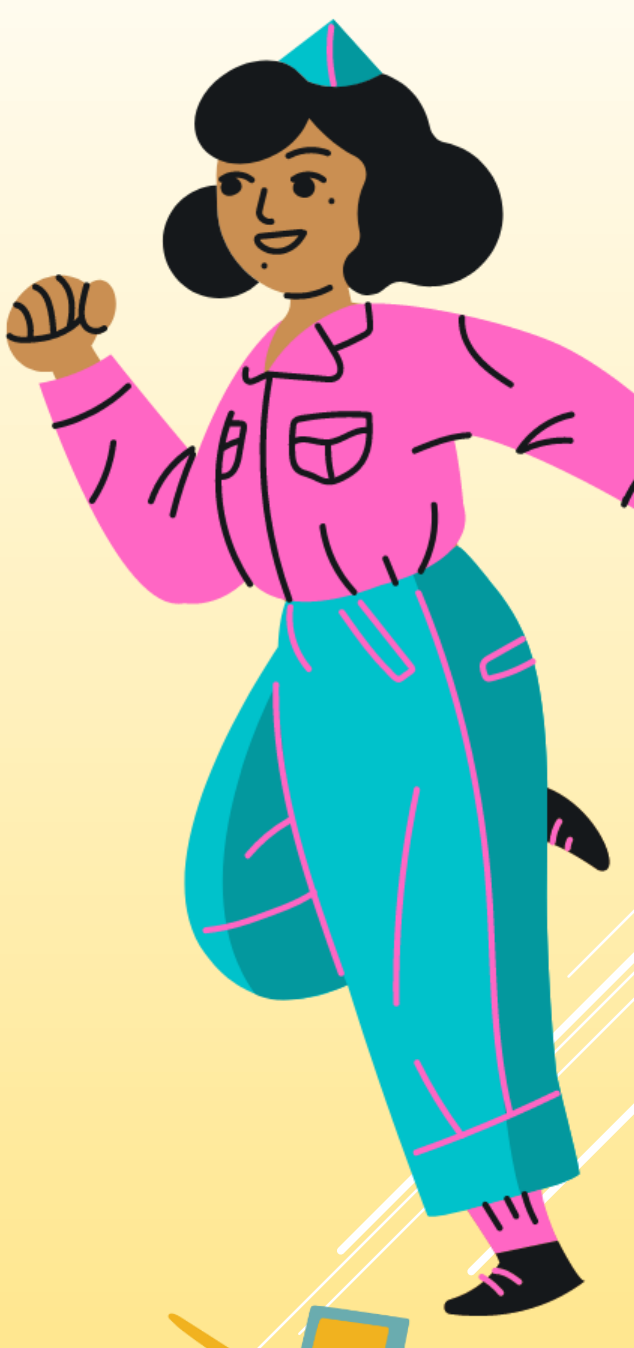



Kenuzia Marianne Félix Castro. No começo de 2020, minha vida passava por uma reviravolta. Ciclos encerraram-se e deram lugar a novas pessoas. Umas que trouxeram sentimentos bons, outras ném tanto. Mudanças no meu modo de viver a vida foram necessárias para o meu amadurecimento pessoal. Na pandemia fui do céu ao inferno dentro de mim. Administrar os meus sentimentos não foi fácil. Foi difícil lidar com o autismo sem a escola e as devidas terapias... Houve momentos de caos? Como mãe me senti incapaz, mas Deus sempre está comigo e não me deixa cair. Hoje tudo parece estar se alinhando, devagar mais está. Nada voltará a ser como antes, mas que bom, menina! Passar por tudo isso só está te fazendo crescer e valorizar as pessoas que você ama.

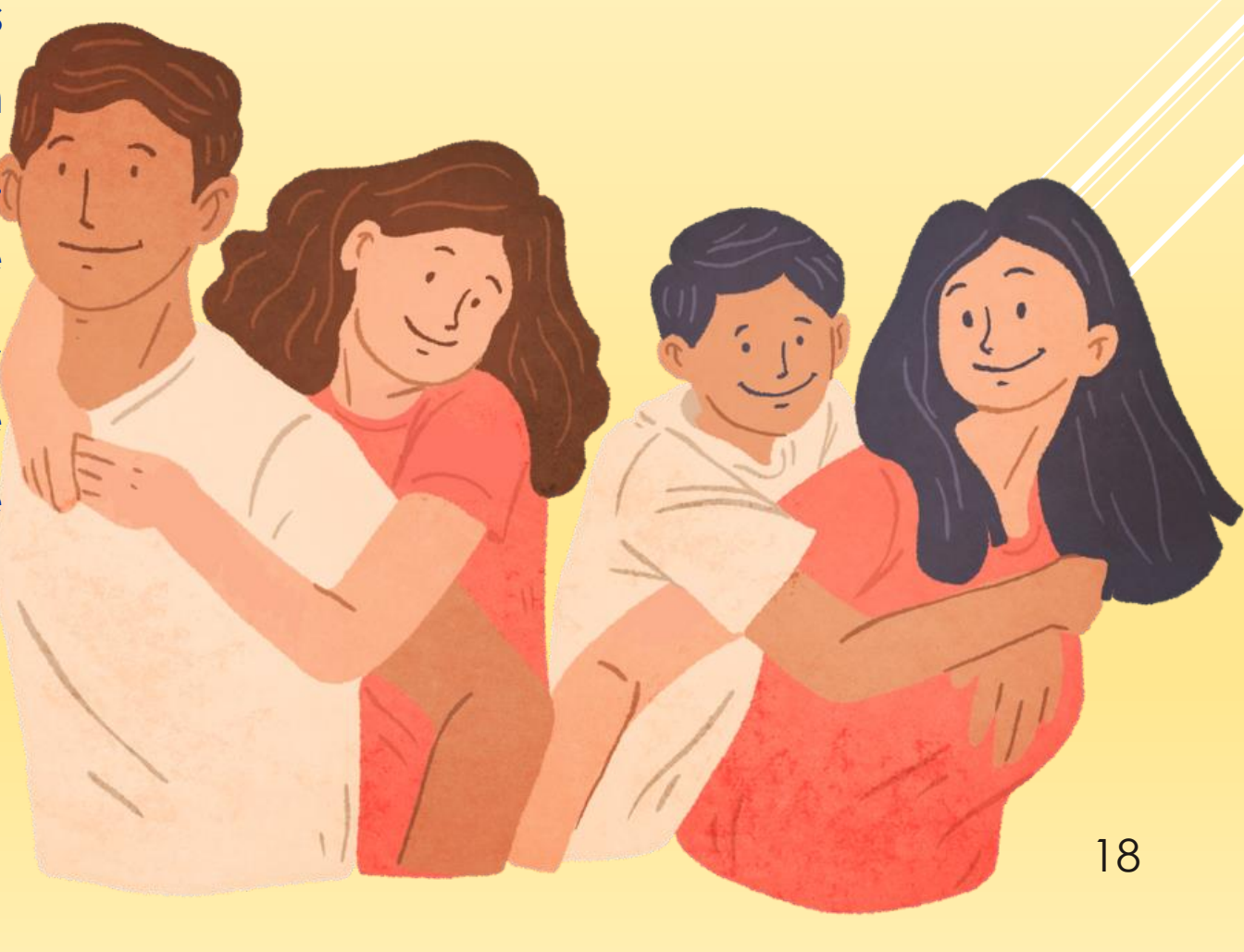




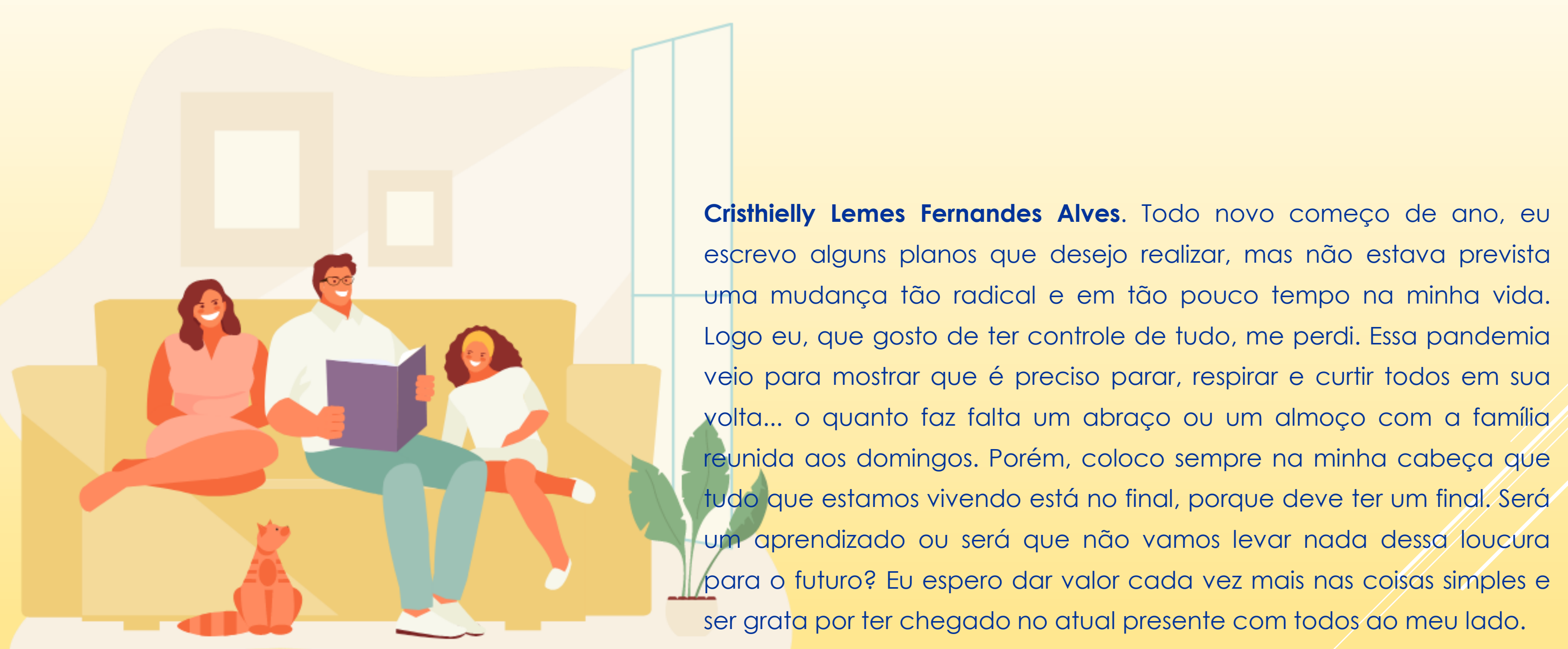


Thalice Coelho Silva. Em 2020, eu esperava um ano de muitas expectativas, pois entraria em um ciclo novo na faculdade e em uma fase nova da minha vida, pois ficaria noiva, mas entramos na pandemia e tudo ficou atrapalhado. Comecei a trabalhar na área da saúde, linha de frente de combate à Covid-19. Não foi fácil porque estávamos num ritmo diferente: distanciamento, uso de máscara... nosso psicológico estremeceu com isso. Passamos a perceber que precisamos de mais amor, carinho, abraço. Thalice, levanta a cabeça segue em frente que você e capaz de superar esse desafio. Deus está no comando sempre. Deus fala: ame ao próximo como a ti mesmo.

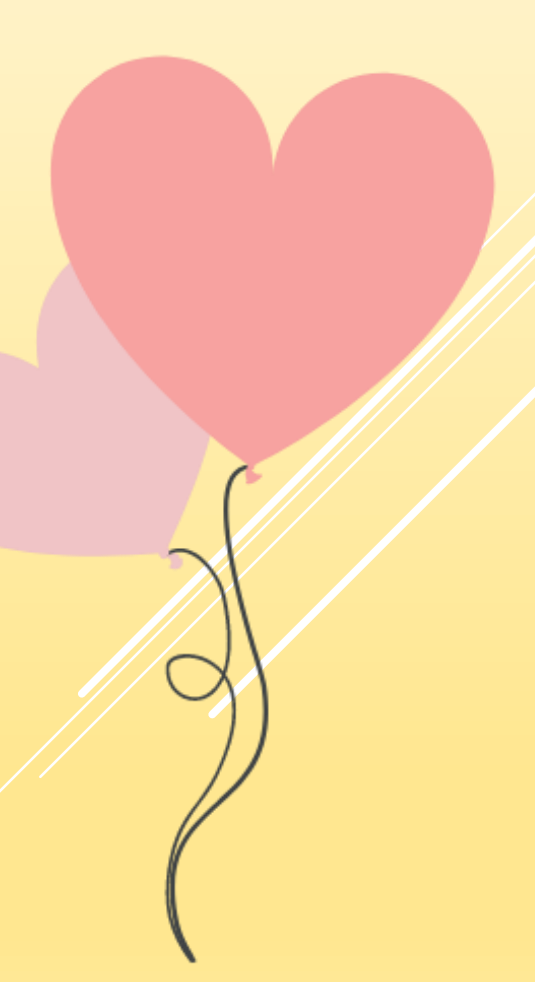


Carolaine Silva Félix. Oi Carol, estou aqui para ter uma conversa com você. Esse ano há muitas surpresas na sua vida. Algumas boas e outra ruins. Você nunca imaginou passar por isso que vai acontecer. A vida de todos vai mudar, e não para melhor. Os estudos vão ficar atrasados, o trabalho vai complicar, não vai ter mais as festas que você gosta de ir... Será um ano difícil. Essa doença que muitos acham ser besteira e alguns acharem que nem existe é muito triste. Graças a Deus, nenhum familiar seu foi morar com Deus por causa dela, porém você sentirá na pele o que essa doença faz, e quase perderá seu avô. Mas, ele é forte e passará por mais essa barreira. Além de não poder sair de casa e fazer as coisas que você gosta, vai ter coisas boas também. O seu sonho vai começar a se realizar. Você terá algumas conquistas com seu esforço. Como felicidade não dura muito, você acabará perdendo seu emprego. Deus sabe o que faz e você conseguirá colocação muito melhor. Pense: você vai poder se dedicar aos seus estudos, aprender coisas novas, seguir caminhos diferentes.

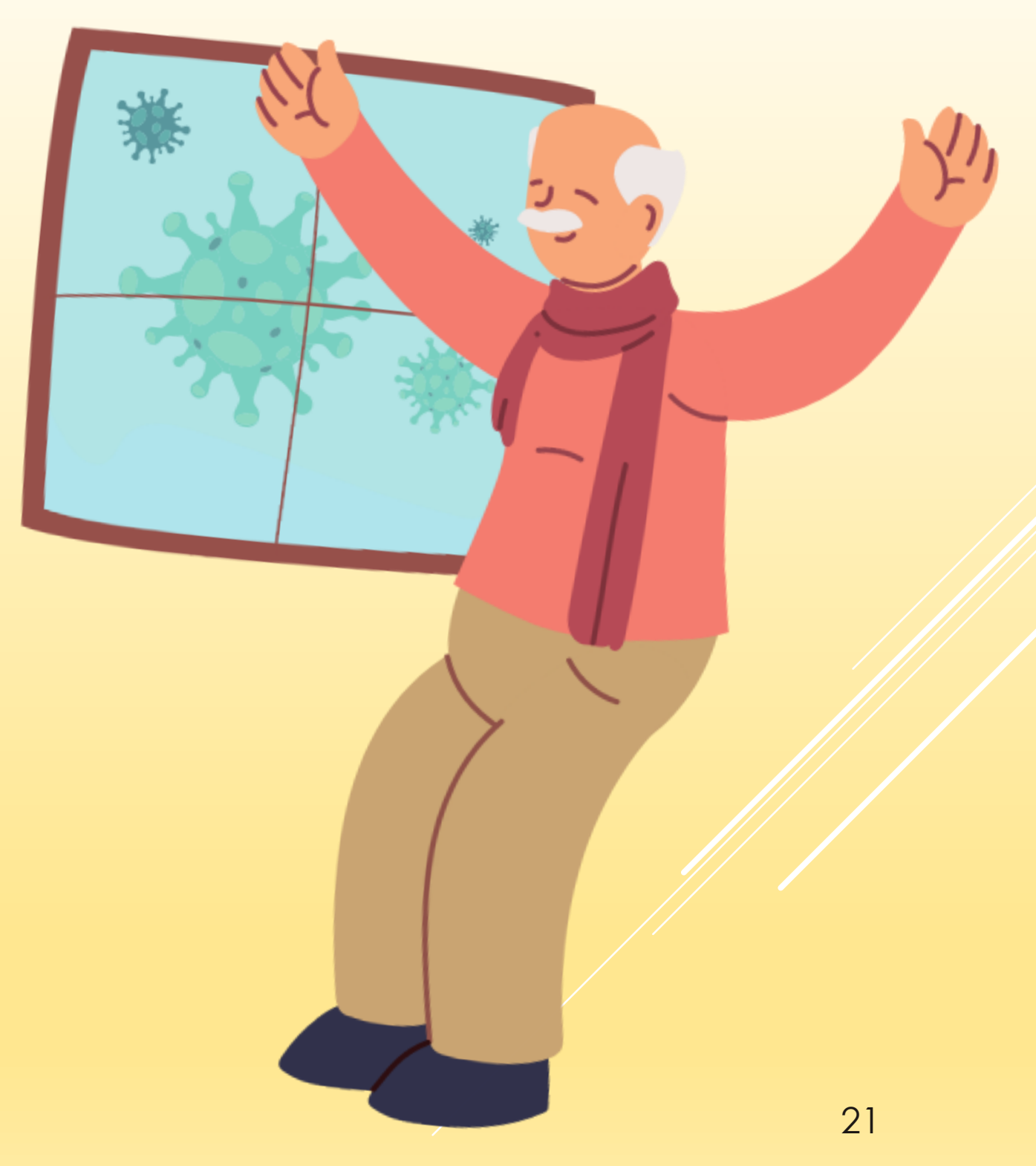




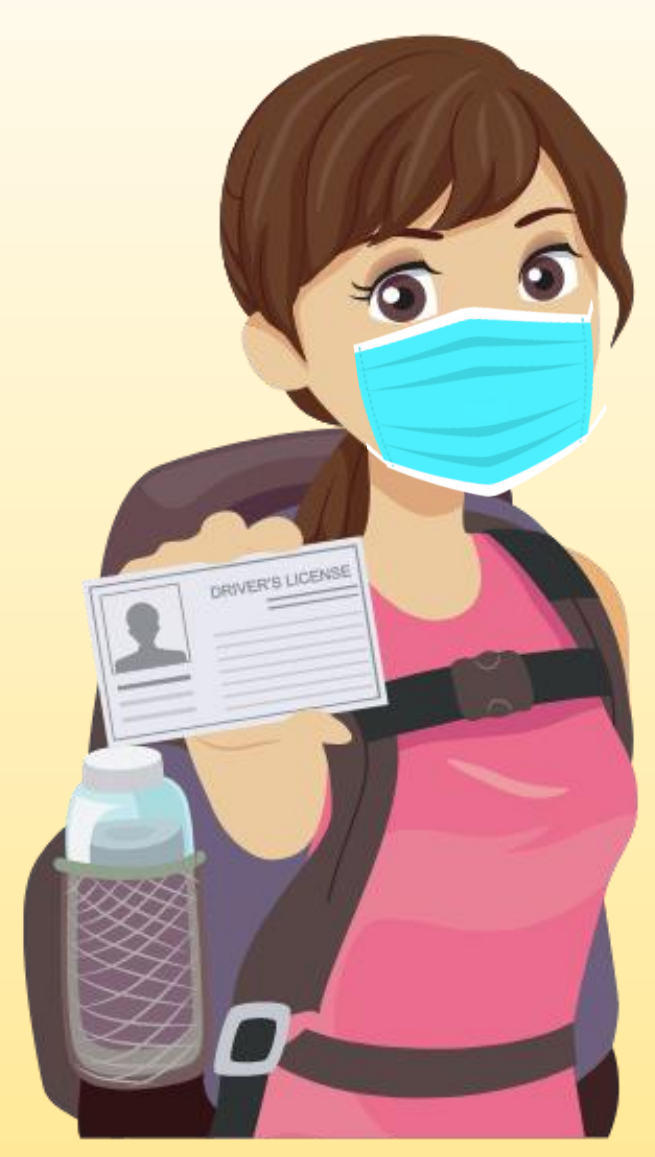

Cristina Aurora Brito de Oliveira. Quem diria que você está onde esperou por tanto tempo: ter seus tão esperados 18 anos, com sua moto e sua carteira. Com certeza, foi uma grande conquista. Só não esperava que você estivesse vivendo esses momentos no meio de uma pandemia. Não poder, infelizmente, comemorar seu aniversário em uma baladinha ou em uma festa..., mas o importante é que todas as pessoas que convivem com você estão com saúde. Portanto, não dá para imaginar as coisas que estamos vivendo hoje. Parece coisa de filme de terror. Não vejo a hora disso tudo acabar para tudo voltar ao normal. No entanto, tudo isso nos ensina a dar mais valor nas coisas: ao trabalho, às pessoas que estão ao nosso lado, à família, e ao quanto é bom respirar! Cris, você saiu do ensino médio sem saber direito o que queria, hoje está na UFU, cursando pedagogia. Não era especificamente o que queria, não é mesmo? Mas vai por mim, você está começando a gostar e a se identificar. Por ora, quero dizer que me orgulho da mulher que está se tornando e nunca desista dos seus sonhos!!

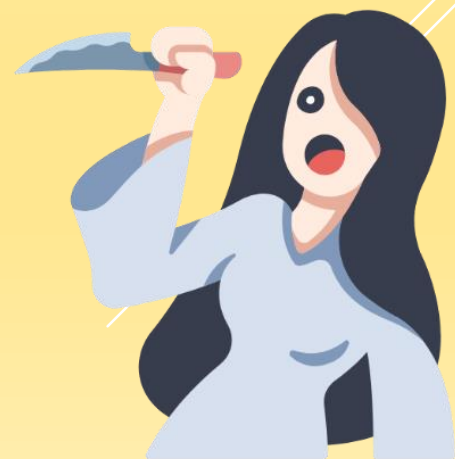


Carolaine Lourenço Pinto Remedi, com esperanças de um ano novo, vida nova, você pintou o cabelo como de costume. Mudou de casa, estava animada juntando dinheiro para comprar os móveis e com saudades dos seus amigos. Saudades essas que, infelizmente, não foram sanadas. Ver-se obrigada a voltar para a casa da sua mãe, passar o dia sozinha e sem poder sair... Tudo isso traz lembranças de tempos sombrios que acreditávamos já terem sido superados. Sei que parece difícil e que voltamos à estaca zero, mas não
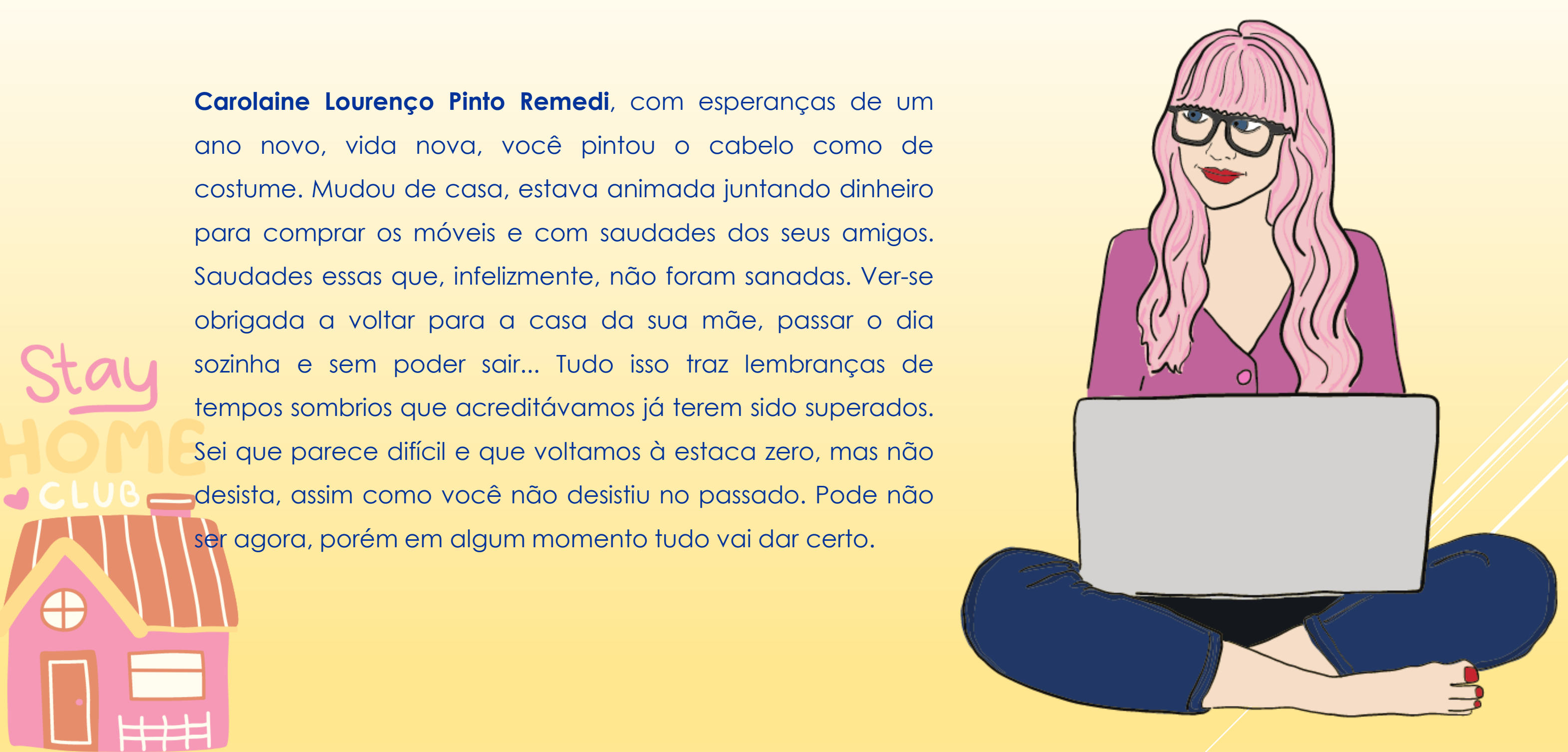


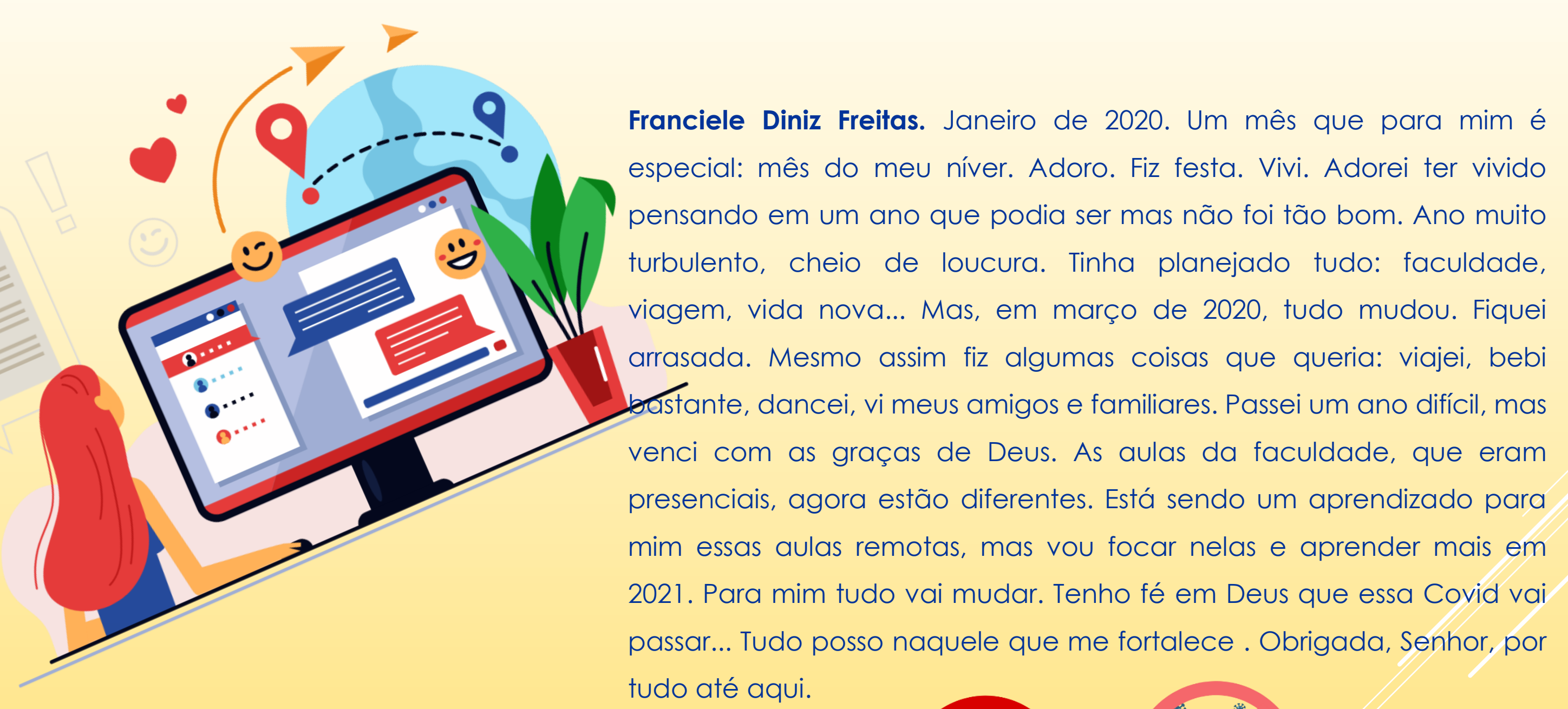
tudo até aqui.

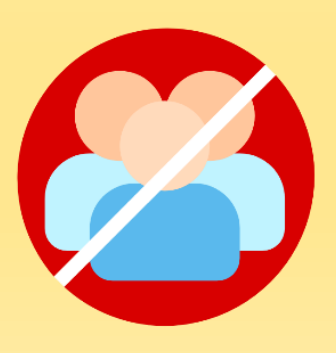



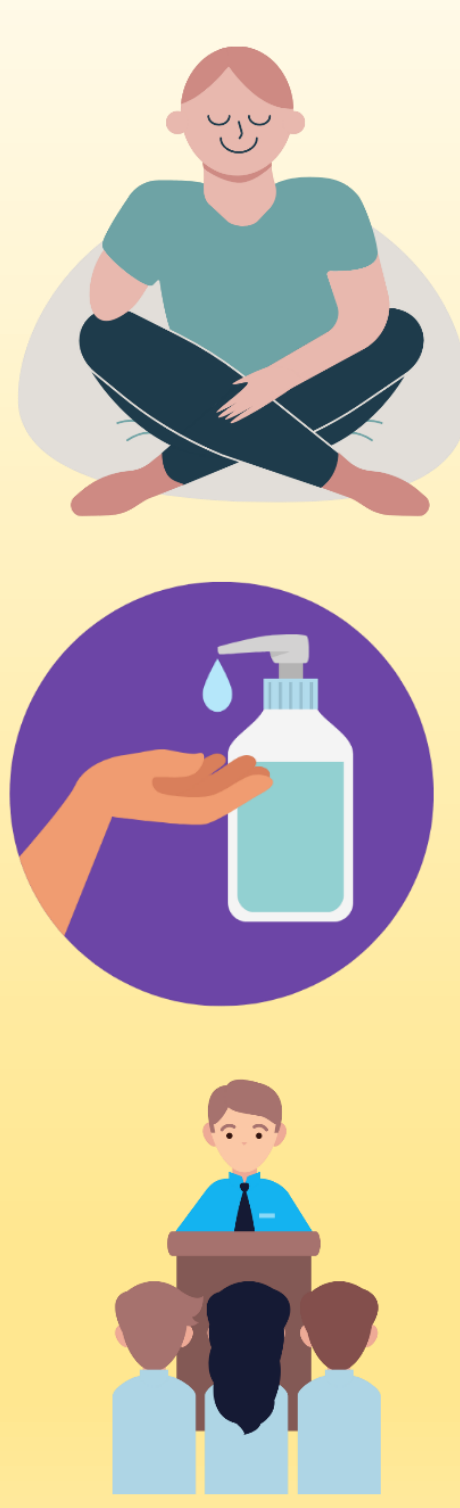

Lucas Mendes. Com 29 anos, estou no recomeço da minha vida. Tem dois anos que meus planos mudam toda semana. Ter calma e bons pensamentos é fundamental. Por mais difícil que seja o momento que todos estamos passando, creio que tudo tem seu caminho e seu tempo de acontecer. Agradeço a oportunidade de recomeçar, pois, como sempre, em toda minha vida, eu admirei e admiro pessoas que fazem a diferença positiva na vida em comunidade. Ao meu ver, ser professor é uma das profissões que mais pode mudar de maneira extrema e positiva a vida de outro ser humano. Por isso escolhi essa linda e desafiadora profissão. Não vou deixar esse meu sonho acabar por nada nesse mundo. E já agradeço as oportunidades que venho tendo e desejo saúde e sorte para todos, pois precisamos.

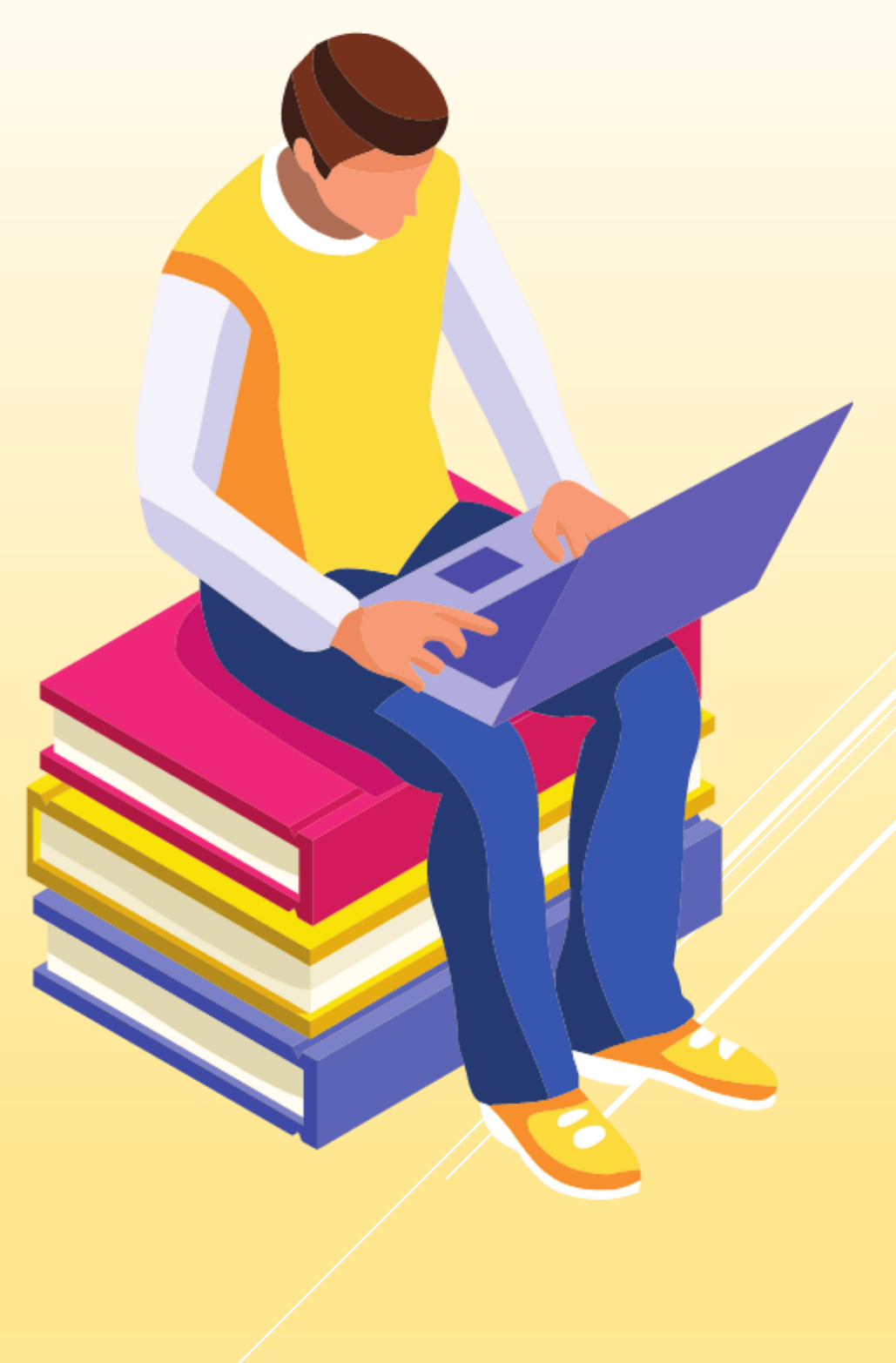


Lidiane Bernardo Batista Bernardo. Ei, quantos sonhos né?̣! Muitos impossíveis. Então, a vida é assim: muito difícil mesmo para uns, mas para você nem tanto, já que você veio pra lutar e não se dar por vencida. Tenha fé que tudo vai dar certo no final. A vontade de desistir é muito grande todos os dias, porém, com o novo dia, tudo se renova. Assim, apesar dos obstáculos, vamos lutar, mesmo sem ter certeza se chegaremos em um lugar melhor. Você já conquistou muito, é um alicerce de família admirável. Parabéns e fé em Deus sempre.
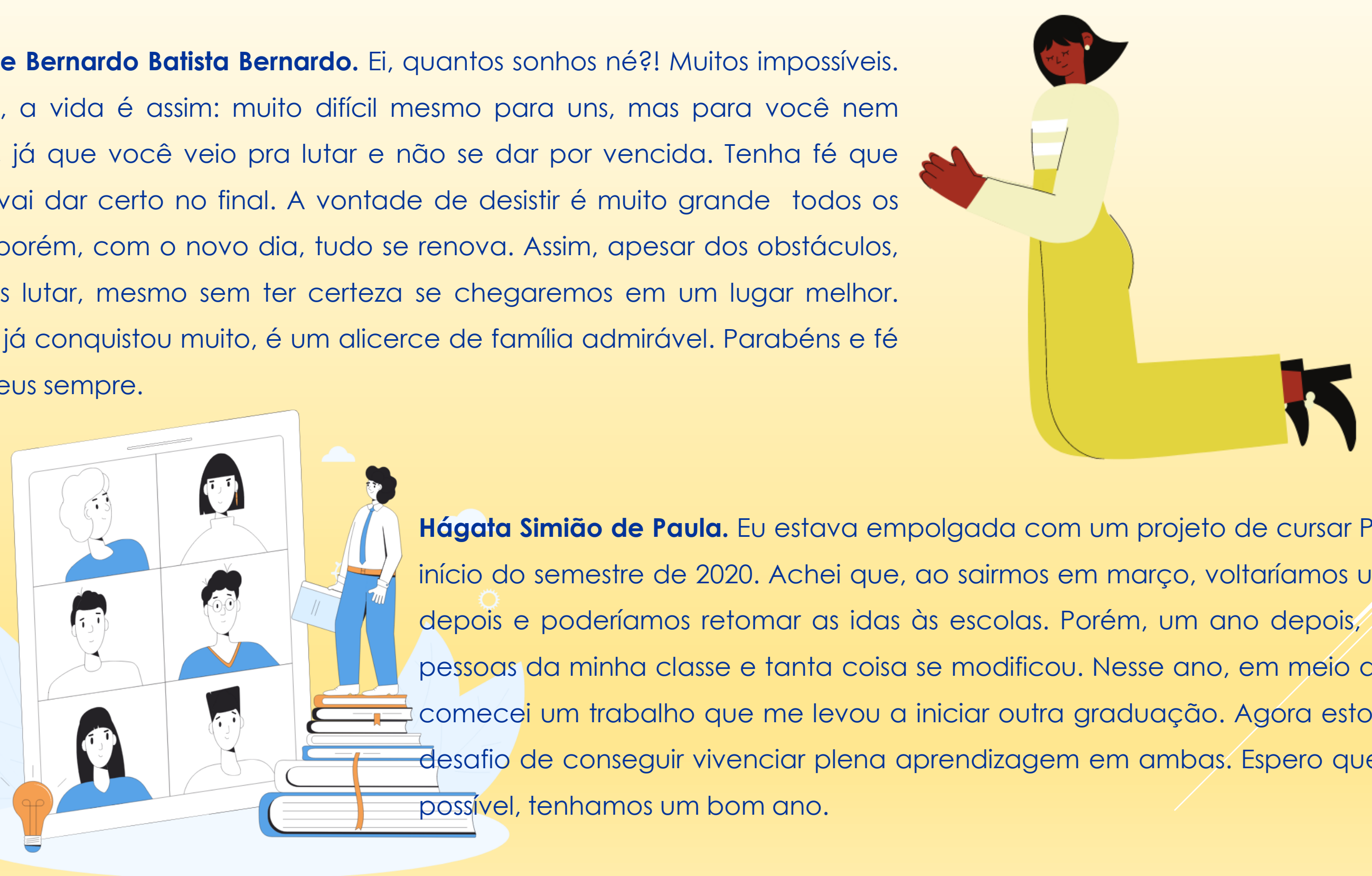

Hágata Simião de Paula. Eu estava empolgada com um projeto de cursar Psicologia no início do semestre de 2020. Achei que, ao sairmos em março, voltaríamos uma semana depois e poderíamos retomar as idas às escolas. Porém, um ano depois, não vejo as pessoas da minha classe e tanta coisa se modificou. Nesse ano, em meio a pandemia, comecei um trabalho que me levou a iniciar outra graduação. Agora estou vivendo o desafio de conseguir vivenciar plena aprendizagem em ambas. Espero que, dentro do possivel, tenhamos um bom ano. 
Natália Martins. Olá, tudo bem? Vai parecer super estranho, mas sou você do futuro. Você vai começar o semestre de 2020 cheia de expectativas, animada com por estar no $3^{\circ}$ período, mas logo isso vai mudar. Vai haver uma pandemia a qual você nunca imaginaria chegar ao Brasil por ela ter começado do outro lado do mundo. Muitas pessoas vão perder suas vidas para esse vírus, inclusive crianças. Isso vai lhe aterrorizar, pois sabemos que o seu ponto forte é também a sua fraqueza: seus filhos. Claro que sua família é sua base, mas você se preocupa por eles serem pequenos. São eles os que mais irão sofrer com tudo isso pelo fato de não poderem ir para a escola, brincar com os coleguinhas, visitar a vovó e o vovô, brincar na praça... Infelizmente seu marido ficará muito gripado e seu filho, uma forte infecção de garganta. Porém, até esse momento, você não compreenderá o que estava acontecendo. Ainda bem, senão você surtaria. Logo depois, você também irá adoecer. Ficará com falta de ar, apresentará um cansaço extremo, vômitos, falta de apetite... Então, virá a notícia de que seu marido e seu filho tiveram Covid de forma branda, assim como sua filha, que não apresentou nenhum sintoma. Já você apresentou sintomas mais fortes. Mesmo depois, você não vai conseguir ingerir alimentos pesados e o cansaço vai demorar a ir embora.

Você vai se decepcionar muito com uma pessoa que você acreditava ser sua amiga e, na verdade, não era! Por outro lado, você vai se aproximar de uma pessoal incrível. Essa sim será sua amiga. Você se lembra quando estava grávida do Miguel? Era ela que conversava e a voz dela acalmava vocês dois. Pois bem, na pandemia, você ganhou uma amizade para levar para a vida!

Você vai conseguir entrar na Iniciação Científica com a Mical no PIBID. Não vou te enganar: não será fácil, pois, além das disciplinas, terá mais essas duas outras atividades, sem falar no acompanhamento de tarefas das suas crianças. Haverá dias em que você irá chorar muito pela incerteza do amanhã, querendo apenas ficar brincando com seus filhos sem pensar em suas obrigações com a faculdade. Mas você vai aprender a se expressar melhor do que antes. Conseguirá, inclusive, conquistar sua carteira de habilitação, mais um passo para sua independência. Sei que haverá pessoas que farão você não acreditar em si mesma e em seu potencial, afaste-se delas. Ter fé que tudo vai passar é o importante. Sua família está unida e com saúde. Precisamos ter fé de que dias melhores virão!

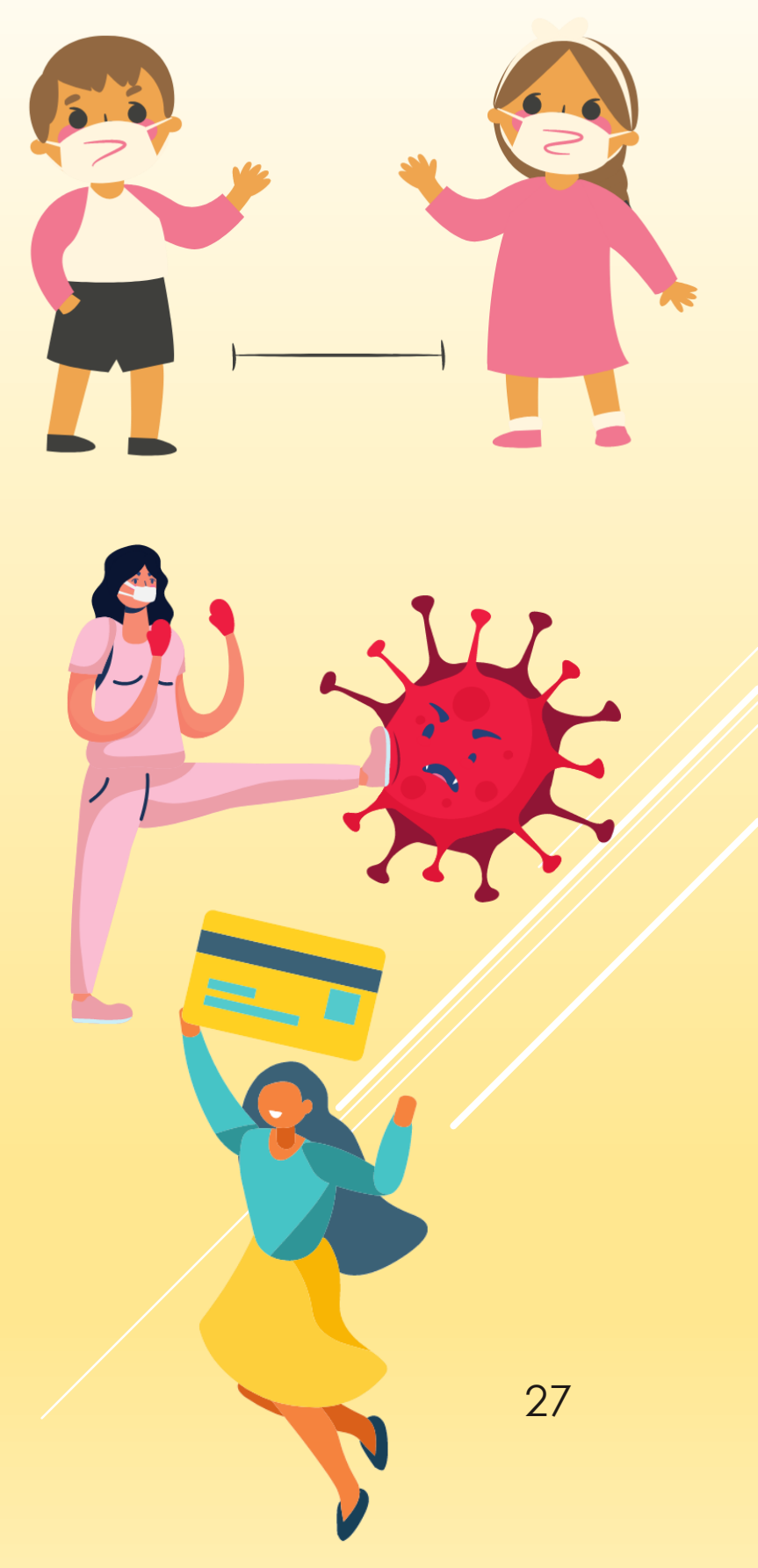


Luana Maciel do Nascimento. E aí, Luana, de boa?! Estamos em março de 2021 e muitas coisas aconteceram ao longo de 2020. Tá ligada nas viagens que tão no pente? Esquece. Se ainda der tempo é melhor nem pagar as passagens e o visto, para não ter dor de cabeça solicitando reembolso. Sagitariana que é, vai ser difícil não fazer trilhas, acampar e ver o mar, porque a única viagem que vai fazer é do quarto para a sala. Mas, pelo menos terá a companhia de um cachorro, uma gata e um namorado. Nossa, sei que deve estar pensando que nunca na vida vai se relacionar antes do mestrado, muito menos cuidar de animais de estimação. Como se não bastasse, ainda vai passar as tardes fazendo tricô, crochê e filtros dos sonhos. Ah, sim, ia me esquecendo, você vai morar a $4 \mathrm{~km}$ do campus. Falando na UFU, deve estar assustada, pensando como vai pedalar pelo menos $8 \mathrm{~km}$ por dia para ir e voltar da faculdade. Fica tranquila, as aulas serão virtuais. Uma coisa boa é você já ir se ambientando com Teams, Meet e RNP. Sei que ainda não faz ideia do que sejam, mas o quanto antes aprender a mexer nessas plataformas será melhor. Ah, falando em melhor, compra uns pacotes de arroz, aproveita que está barato, porque vai custar R \$ 40,00 (quarenta reais)! Se puder, compra "uns" feijão, óleo, álcool e mascara também. Deve estar se perguntando, pra que vai comprar comida se almoça e janta no RU? ! É porque ele não vai funcionar. Mas pode ficar de boa que não é você que vai cozinhar. Mano, vai morrer um monte de pessoas ao redor do mundo, o pantanal vai ser incendiado, o dólar vai chegar a quase $R \$ 6,00$ (seis reais), a Amazônia também vai ser destruída e o presidente continuará no poder. Para não dizer que não falei das flores, vai ter CD novo do Inquérito, Xamã, Crônica e o Mc Hariel. Vai ter favela vive 4, poesia acústica 10 e um som top do Mc Marks. Obs.: se quiser continuar solteira não vá ao shopping em fevereiro de 2020.

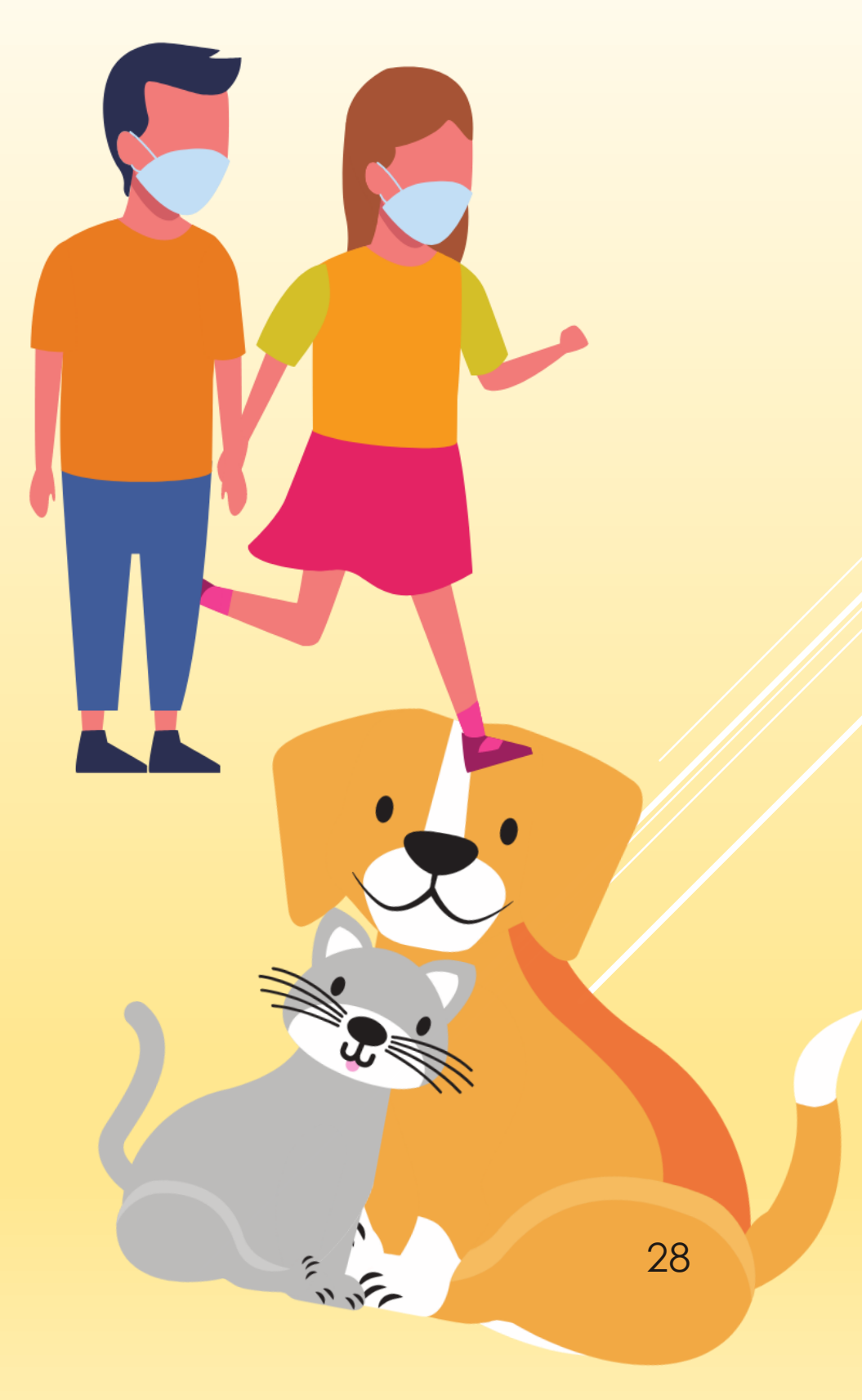




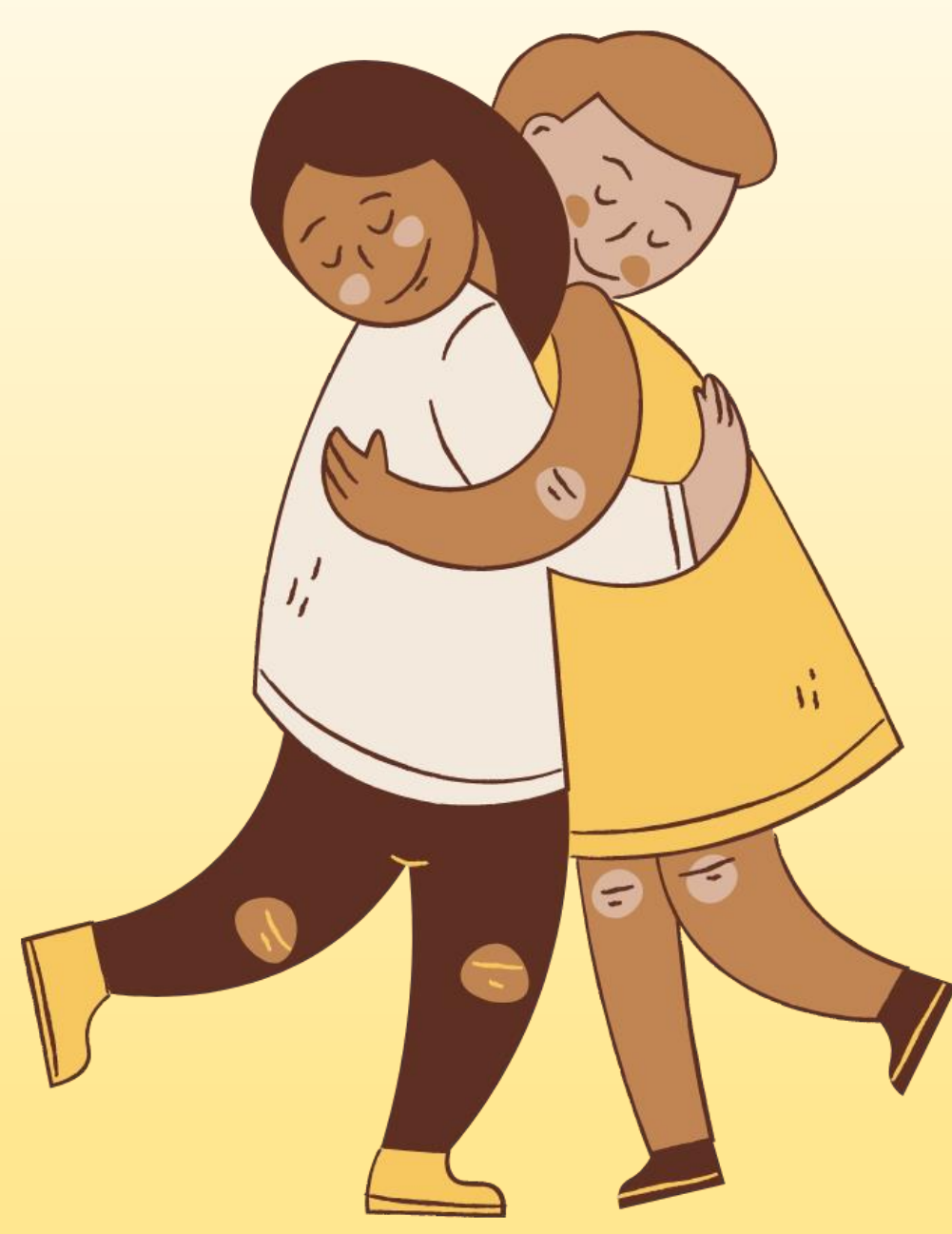

João Vitor Santos Silva. Olá João Vitor, tudo bem? Espero que esteja bem. Venho aqui pedir pra você se preparar bastante para o ano de 2020. Dê uma atenção especial para a sua saúde mental, pois muitas coisas vão acontecer e você precisa ser forte para apoiar sua mãe. Aproveite as músicas. Elza Soares vai participar de uma maravilhosa, eu recomendo! No mais, quero que continue acreditando em seus sonhos, e seja firme. Vai haver uma pandemia no Brasil e em todo mundo. Infelizmente familiares seus vão ser contaminados, e nem todos irão aguentar. Mas permaneça esperançoso, pois os cientistas estudarão vacinas para a doença, vai demorar, mas vai ser criada. Enfim, curta os momentos com sua família e amigos da melhor maneira que é possível, com as novas medidas que surgirão. Felizmente você será contratado novamente em 2021, depois de muitas incertezas e aflição, você terá essa ótima oportunidade. Sua amizade com a Edilaine vai crescer muito nesse período e vocês vão se ajudar bastante nas adversidades da vida. Espero que seja bem feliz, e aproveite com muita saúde! Grande beijo. 
Mayara Dias da Silva. Olá. Como está o planejamento para a formatura? "Olá, preciso começar os preparativos da festa de formatura 2021, tenho que pagar, experimentar vestido, pensar qual salão fazer maquiagem, cabelo, na quantidade de convites. Muita coisa pra pensar e planejar. Novembro está muito próximo e não sei nem por onde começar..." Kkkkkkkkk. Tá sonhando. Pode ficar tranquila. Como está indo a pandemia, até novembro não terá festa, pois não pode ter aglomeração. Mas continue juntando dinheiro, porque a dívida você tem que pagar. A festa vai ser adiada, mas a dívida não. kkkkkk. E no dinheiro que pensa em gastar com vestido e maquiagem, guarda pra pagar a festa. Enquanto isso, no meio desse caos, fique em casa em isolamento com sua filha linda, que será o melhor tanto para você quanto para ela. O melhor a ser feito é se isolar, porque somos seres indefesos perto desse vírus, pois não vemos de onde vem, nem para que lado vai. No fim de tudo isso, você vai ter sua festa de formatura, sentir arrepio e a vergonha de descer a escada do salão de festa...
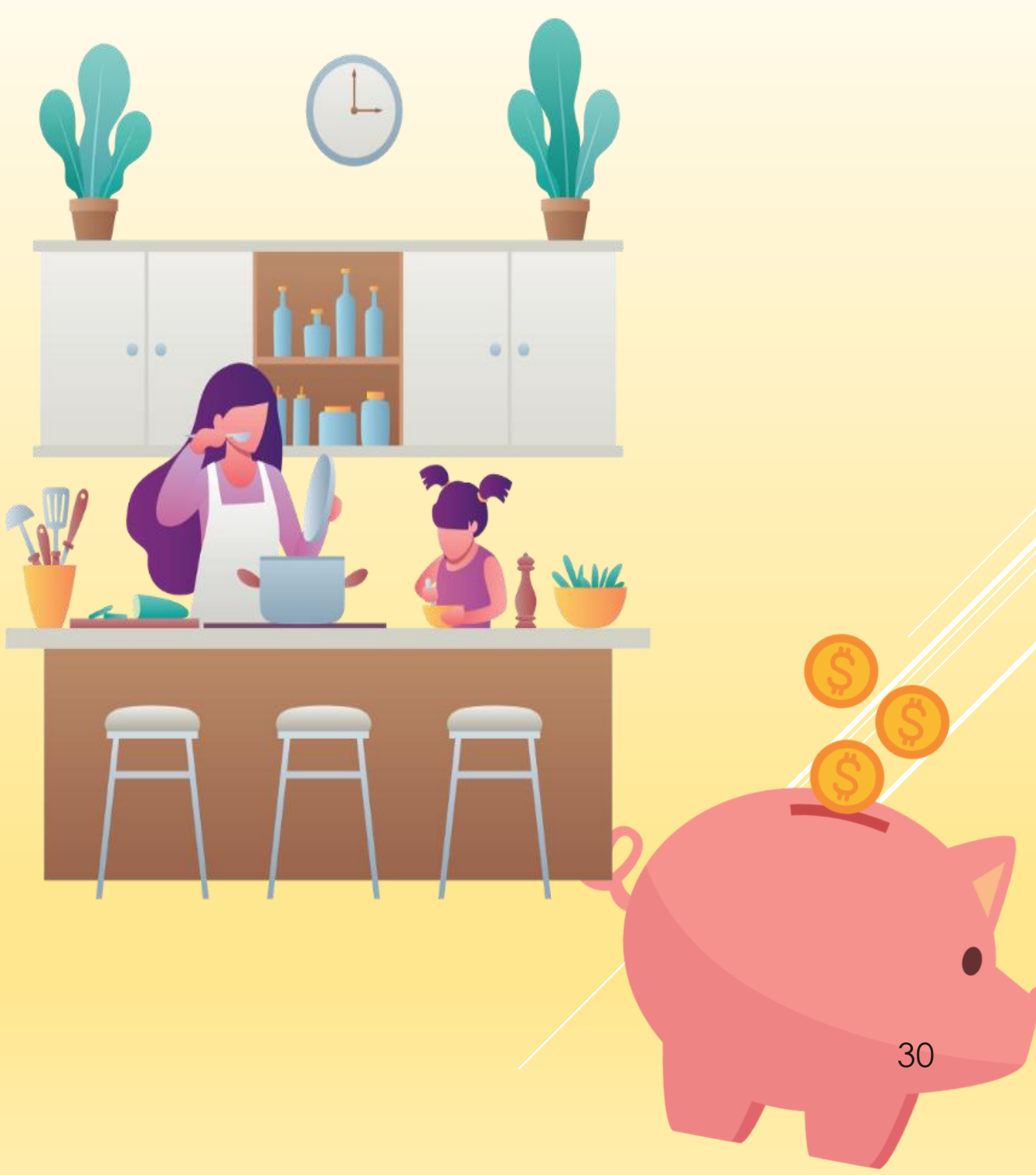
Oi Edilaine de 2021, sua linda. Querida, precisamos conversar. Tenho informações valiosas pra você, e talvez eu consiga te ajudar a ficar mais tranquila. Todos aqueles planos que você está fazendo, é bom rever. É possível que a paz não reine como você gostaria. O mundo agora está um caos, e as pessoas se recusam dia após dia a acreditar nisso. Hospitais sem leitos disponíveis virou rotina. O cansaço físico e mental, tomou conta de todo mundo. E aparentemente a grande parte da população desse mundão nosso, nem liga. Você vai passar por muitos problemas pessoais. Sua filha, aquela criança abençoada, vai precisar de você mais do que nunca. E você vai precisar se reestruturar para conseguir atender as novas demandas. O sonho que você tinha dela estar com você, vai chegar antes do planejado, mas você estará pronta e fará seu melhor. Aquele festão de formatura que você tanto almeja?!! Por enquanto, esquece. O que você poderá fazer é tentar levar as coisas da melhor forma possível. Mas em meio a tantos percalços, você irá conseguir se ver por dentro, e irá conseguir se cuidar. Cuidar da sua saúde (que por sinal você tem deixado de lado né, bonita?!) Cuidar principalmente da sua saúde mental. E o plano é o seguinte: quando você achar que não consegue, quando você achar que não é capaz, você vai respirar fundo, e vai lembrar de tudo que já passou, de tudo que já suportou. Quando você se lembrar disso, vai entender que consegue sim. A sua visão de mundo irá conseguir te ajudar muito nisso, pois o seu modo de ver o lado bom das coisas não vai deixar você se afundar e, ainda, poderá ajudar quem está a sua volta a encarar a vida com mais leveza. Já vai ter tristeza demais. Então fica firme, que tem pessoas que dependem de você emocionalmente. E continue acreditando que as coisas irão melhorar, mesmo ainda não vendo a luz no fim do túnel. Se não tiver nenhuma, pelo menos você viveu do melhor jeito possível. Continue cuidando de você, isso não é egoísmo. E eu estarei aqui pra te ajudar a entender o quão capaz você é. Mil Beijos. Com amor, Edilaine de

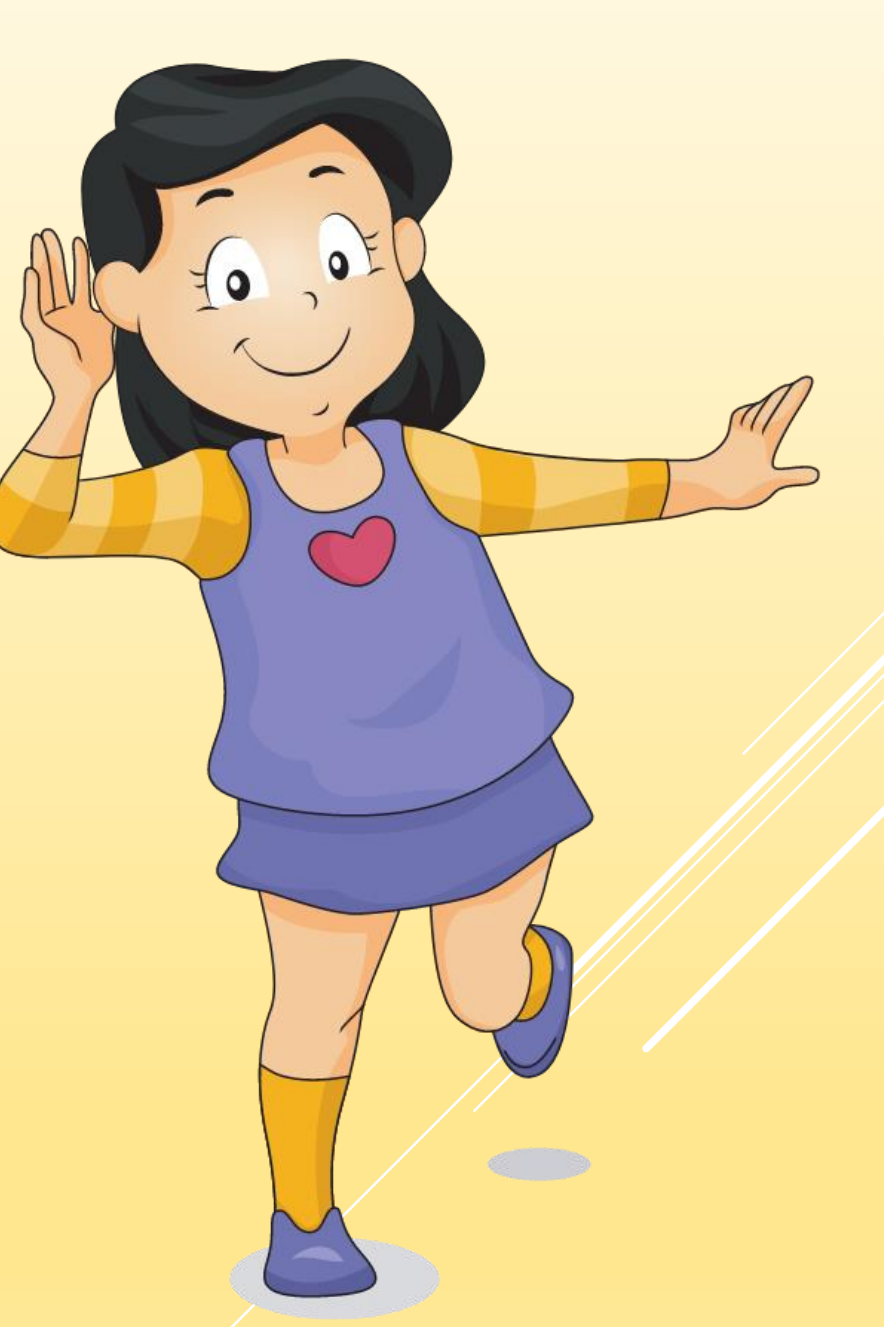

31 2020. 


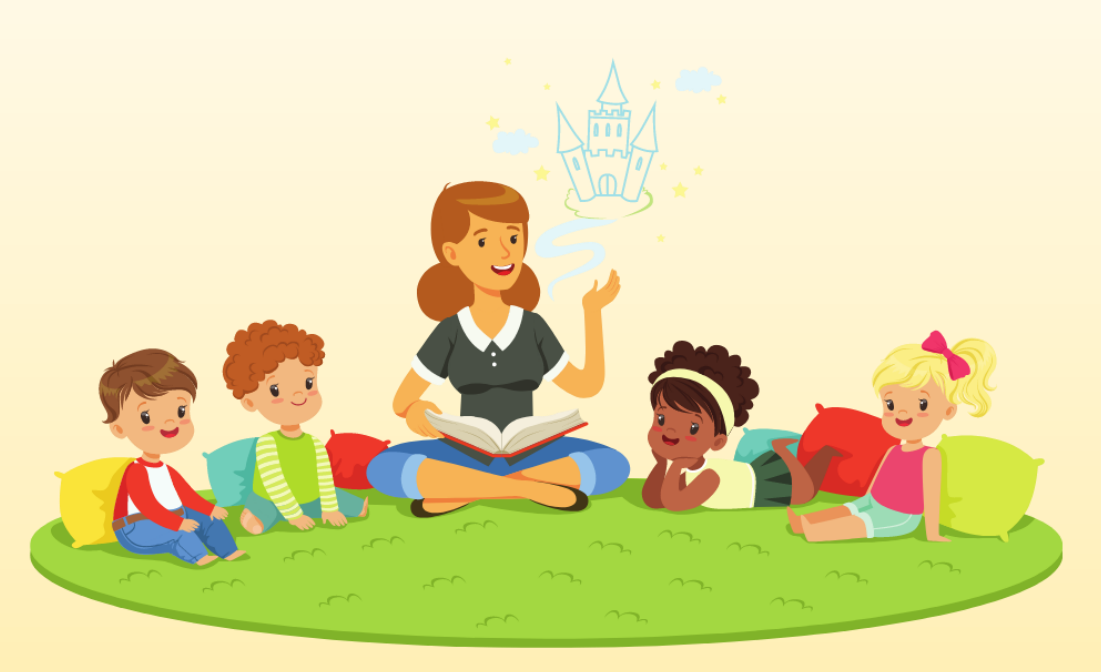

Caroline Martins Ferreira. Oi Carol. E aí, como estão as coisas? E a faculdade de Agronomia que você sempre quis? Pois é. Você desistiu desse sonho. Não quis cursar aquela vaga para o curso de Biologia e por pressão da família, acabou pegando sua nota do Enem e jogando para o curso de Pedagogia, pensando que não iria passar. Você conseguiu. Porém, chegou a ficar um tempo sem ir para a faculdade porque não era aquilo que você queria. E no fim, você está aí terminando curso de Pedagogia. Você chegou a trabalhar 2 anos como auxiliar de professora em uma escola infantil, com crianças de berçário. Foi aí que você descobriu o seu interesse e sua paixão pela educação. E foi isso que fez você querer continuar o curso. Lembra que não queria ter filhos? Pois é. Você teve um, que hoje é o seu grande amor. Você dá a sua vida por ele. Tudo que tinha planejado... algumas coisas você terá que desistir. Mas agora terá novos planos e nesses uma pessoinha fará parte. Um conselho. Nunca faça nada sem pensar e comece a ouvir seus pais e seus amigos, pois você já fez várias coisas sem ouvir ninguém e acabou quebrando a cara. Agora aproveita a sua vida com o seu filho lindo, que aquele sonho em ir morar em Mato Grosso vai dar certo.

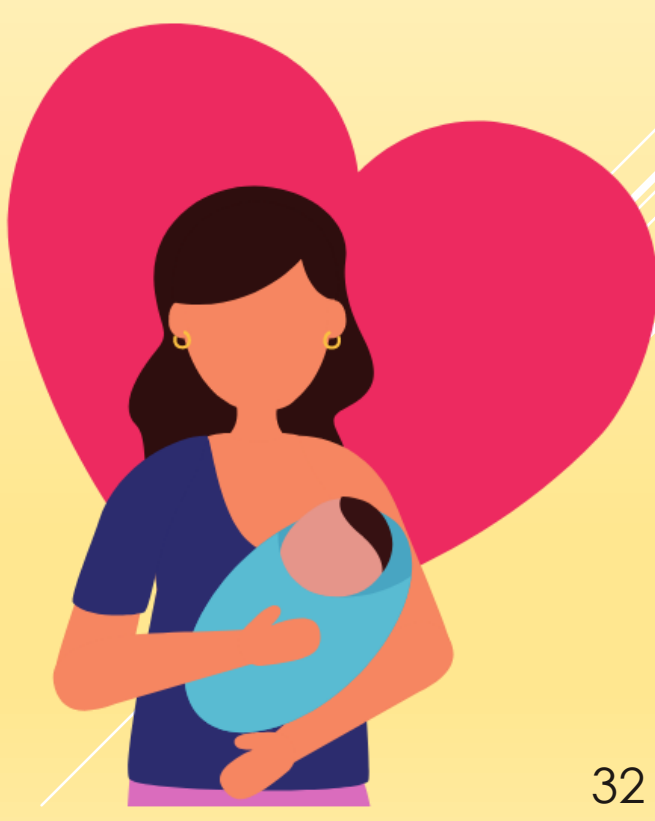

Kamila Meneghin Brito. Oi Kamila. E aí, como tá as coisas? Lembra a faculdade de você nem saiba o que é pedagoga social kkkk mas aqui, no futuro, você é apaixonada pela sua profissão. Lembra que não queria se casar? Pois é você se casou, e depois descasou. E eu posso te falar que nunca te vi tão forte como agora. ue que você é intensa, mas não se se preocupe que tudo passa. Um conselho. Aproveita sua vida. Seu sonho de viajar pro exterior ainda não realizamos, mais vai acontecer. Acredite. 
Nara Adriana Rezende Costa. Oi...Nara... tudo bem com você? Então...sou seu futuro...seu eu...rs... Como vai tudo por aí? Vamos lá... conversar...sabe a faculdade de Pedagogia? Que você teve que trancar por problemas de saúde...este ano de 2020 voltaremos com força total, pois você precisa terminar e está quase lá... Só que terá uma surpresa neste percurso, onde tudo que você planejou sairá um pouco diferente. 2021 será tempo de várias dúvidas e incertezas, principalmente no começo do ano. Mas, Nara, você será forte e guerreira, como sempre foi. Tudo ficará bem no final. Basta você acreditar, confiar e ter paciência. Então...mil bjs e mil abraços, como sempre gosta e com um lindo sorriso de sempre.

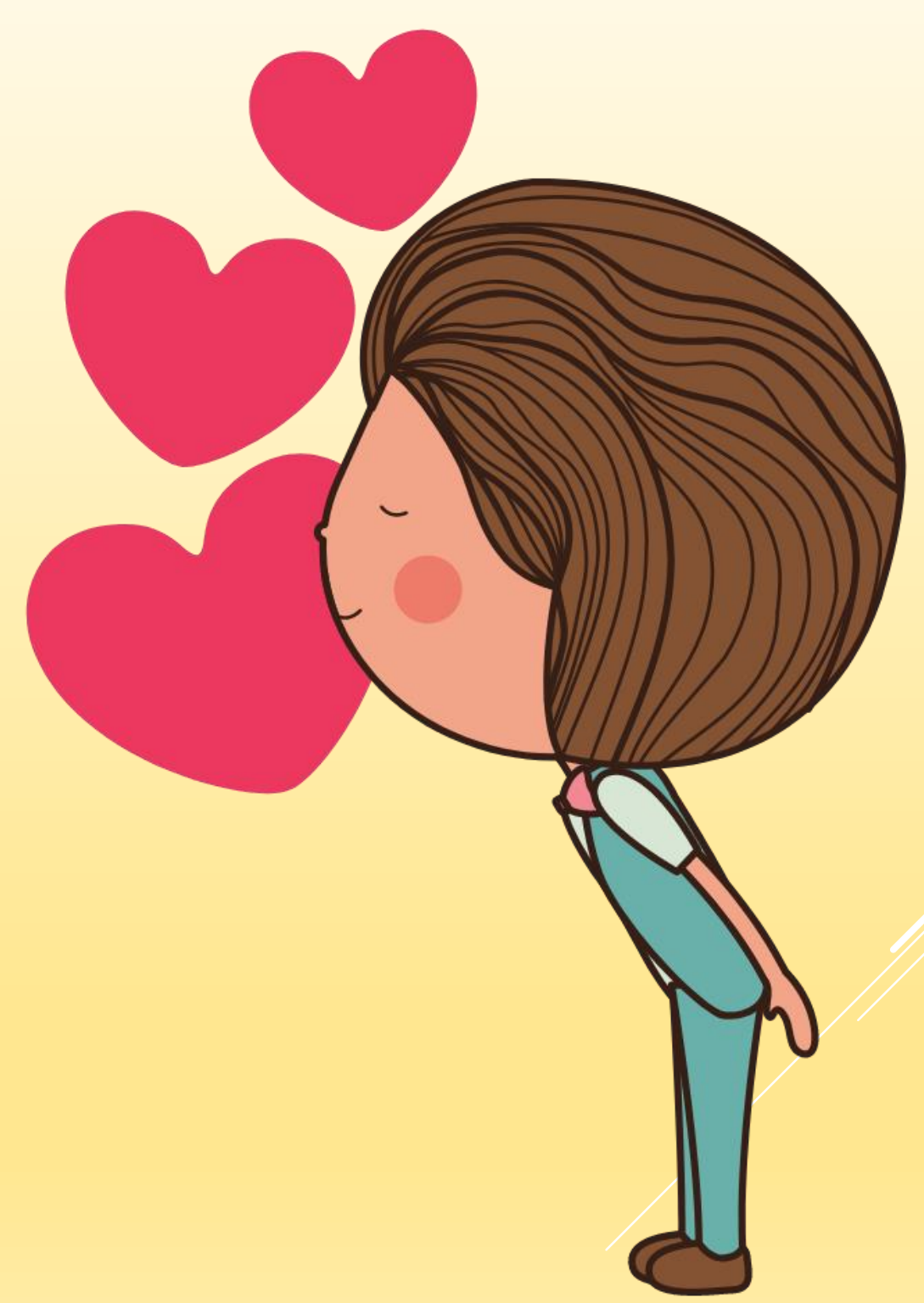




\section{Raquel Moura de Lima.}

- 2020 chegou!

- Então...Raquel, eu sou você! Estou aqui pra saber como passou, mas ainda pra te umas dicas do que ainda está pra acontecer neste 2020, com esse "mundão" particular, com você!

- Ai, ai...está me assustando...você se tornou uma vidente, bruxa sei lá o quê logo!!!

- Você chegou até aqui, janeiro de 2020, passou por grandes desafios, sofreu perdas, mas teve ganhos também. Chegou até aqui mais experiente, está fortalecida $\Theta$ otimista. Com planos nessa empreitada que começou, que se identificou muito que é 0 seu curso de Pedagogia, não é?

- Preciso terminar o curso, me diz que vou conseguir!

- Vai sim. Se planeje, se organize, porque com o que está pra acontecer, talvez terá mais tempo que imagina. Está vindo uma onda mundial, que vai afetar a saúde de todo mundo, financeira e psicológica. Se em seus planos tem viagem, família, festas, como o aniversário de 67 anos do casamento dos seus pais, esquece. Impossível. Sempre reclama da falta de tempo pra se dedicar ao curso por causa trabalho, cuidado...poderá ter esse tempo com a falta do trabalho.

- Nossa quantas notícias ruins...

- Calma... Será tenso, difícil. Mas vai passar. Confie, acredite, se solidarize, exercite a sua fé, se organize, não se procrastine, cobre, exija, se posicione. Ame a si e aos outros sem julgamentos. É isso que tenho pra dizer a você, Raquel Moura. Da sua própria Raquel Moura, sobrevivente de 2020. 
Vanessa Fideles de Paula. Oiie Vanessa, tudo bem?! Sei que você já me conhece, mas quero que você saiba que eu sou você no futuro e vim conversar e te contar um pouco de como sua vida vai mudar em 2020!!! Bom, eu sei que você tem vários planos e sonhos para serem realizados neste ano, sonhos e planos que foram planejados por você há dois anos, antes de 2020 né? Pois bem, senta que lá vem história. 2020 vai ser um ano de grandes conquistas em sua vida. Isso você pode ter certeza, porque tudo que você confiou a Deus será cumprido conforme sua vontade. Apenas confie! Te peço para cuidar da sua saúde, do seu coração, de sua pressão e procure um especialista, pois você vai precisar cuidar da sua saúde menta também. Vão acontecer coisas que você nem vai acreditar, que poderiam acontecer novamente. Você vai se machucar, ficar triste e pensar "por que isso está acontecendo novamente com você". Mas fica firme, que você é mais forte do que imagina. Acontecimentos como viajem, festas e comemoração, você vai ter que esperar um pouco para realizar. Neste ano, você vai perder algumas pessoas que você gosta muito, mas você sabe que Deus tem o melhor para cada um deles. Cuide muito bem de seus avós/pais, pois eles vão precisar muito de você. Sua faculdade de Pedagogia, sua formatura, poderá não ser como planejado, mas você vai dar conta de tudo, mesmo pensando que não. Seu trabalho vai ser um pouco diferente do que você está acostumada a fazer, pois vão acontecer algumas mudanças também. Sei que você vai ficar muito ansiosa. kkk. Então, menininha sonhadora, pra terminar, posso te dizer que 2020 vai ser um dos melhores anos de sua vida, mesmo com tudo que estará acontecendo, pois você tem Deus que sempre cuida de você. Ele colocou em sua vida sua família, seu esposo, seus amigos, que eu não preciso falar quem são porque eles já sabem que sempre estarão com você, em todos os momentos de sua vida. Seja forte e corajosa. Um grande beijo de você para você mesma.

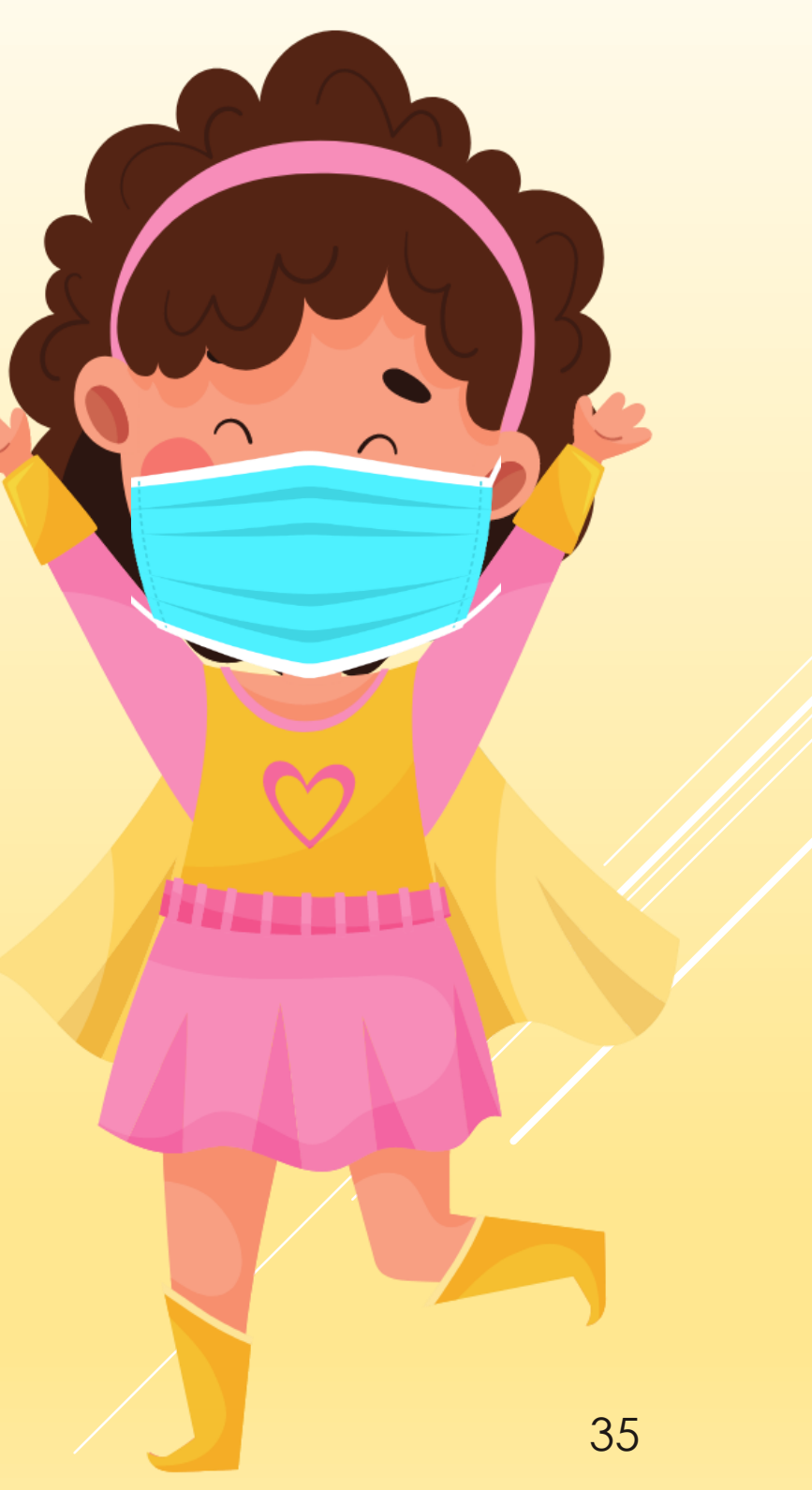




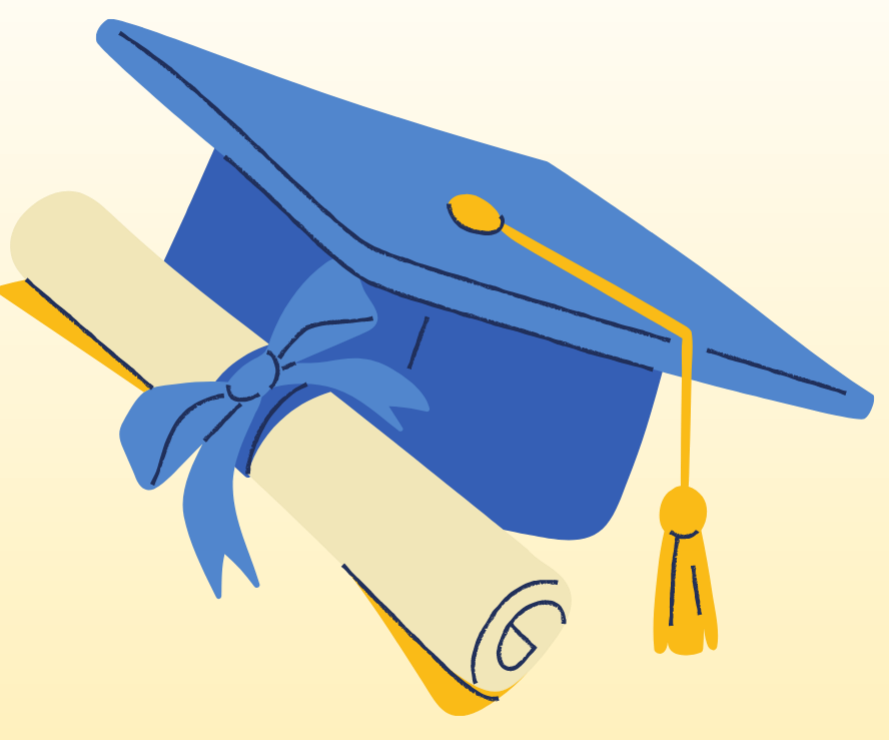

Rafayanne Mamede. Oiii Rafa, tudo bem? Espero que esteja bem, pois o que eu vou te contar agora pode não ser tão bom, quanto você gostaria... Bom, o ano de 2020 não vai ser como você planejou... aquela viajem tão esperada, ela não vai acontecer por enquanto. O trabalho que você está tão feliz e empenhada em realizar, na área que você sempre sonhou em atuar, então... ele terá que ser repensado, pois os métodos de ensino serão modificados. A faculdade não será a mesma. Você não vai ter a mesma alegria em participar das aulas, pois já não poderá ver e abraçar aquelas amigas que são essenciais para você nesta caminhada; não poderá mais trocar aquela ideia com os professores, antes da aula, sobre sua vida, ou até mesmo dar crises de risos com seus amigos no intervalo. Mas não fique triste. Você conseguirá vencer todos os obstáculos que aparecerão em sua vida. Você verá o quão forte é e dará ainda mais valor nos beijos, abraços, no toque das pessoas queridas. Você verá quanta falta faz aquela reuniãozinha familiar e dará ainda mais valor nestas pessoas importantes que tanto contribuíram para você se tornar a mulher que se tornou. Enfim, 2020 não será um ano fácil, mas não será impossível. Você vai conseguir tudo aquilo que almeja e vai sentir o sabor da vitória ainda mais doce, pois saberá o quanto lutou! Não desista, você é capaz!

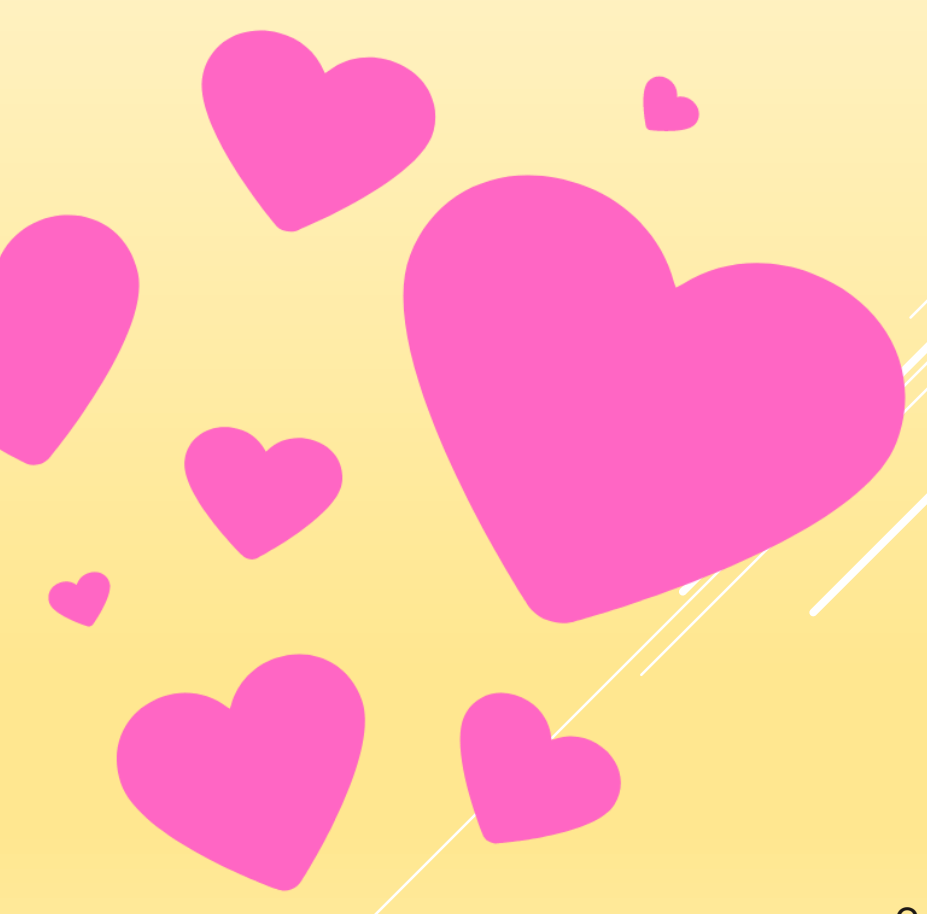




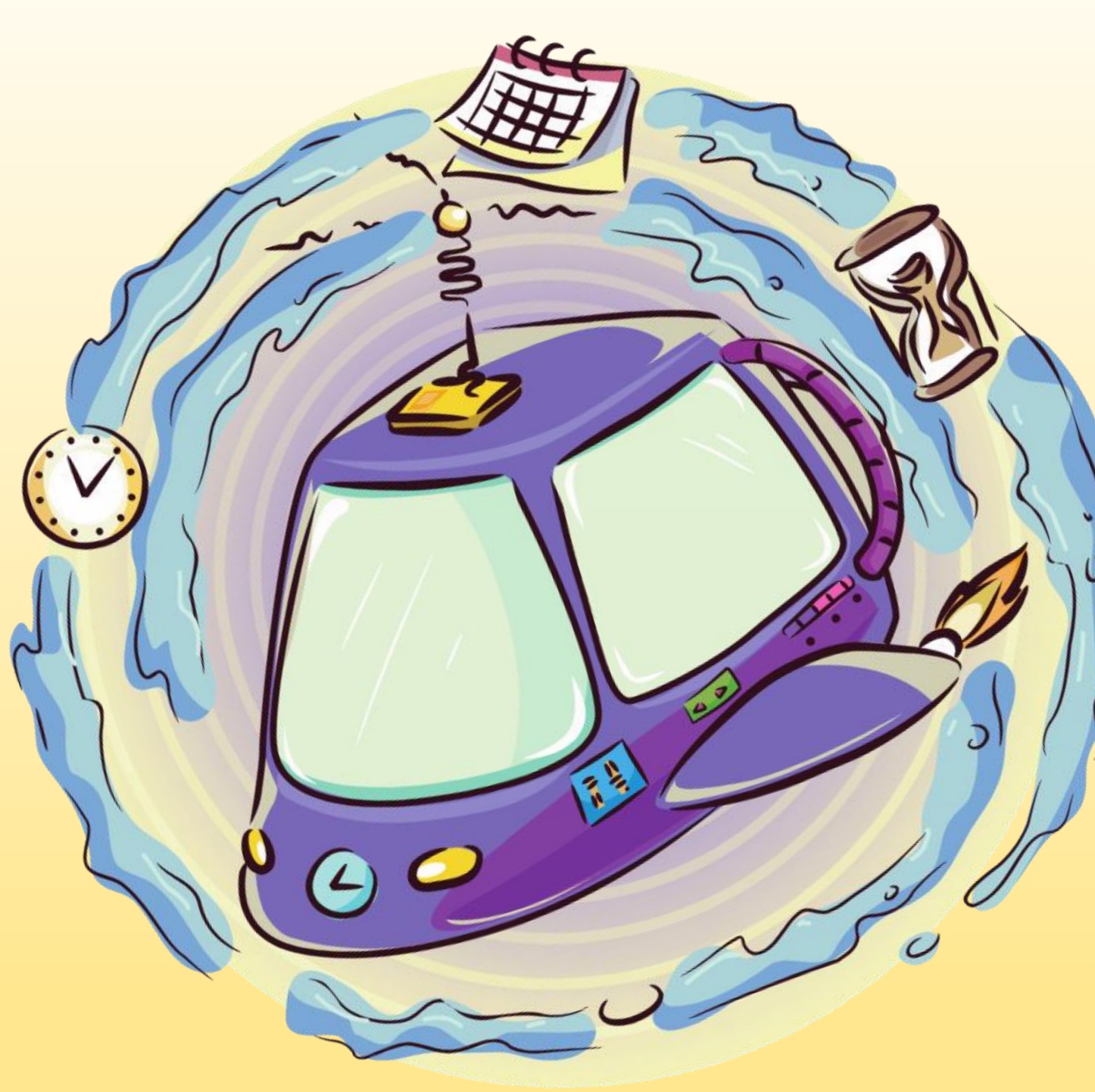

Dielle Oliveira Bezerra. Estava na cozinha tomando um copo de água, me perguntando o que faria da vida desempregada e se a vida continuaria assim, quando escuto um barulho atrás de mim. Tomo um susto com que vejo na minha frente. Limpei o rosto três vezes para ver se estava sonhando. Porém, não era sonho. Via uma figura idêntica a mim, sorrindo, até que ela disse:

Olá Dielle, como tem passado? Melhor. Não precisa responder. Eu já sei. Passei pelas mesmas crises e ansiedades. Eu sei que você tem várias perguntas. Pois bem, vou começar a dizer que você arrumará emprego, mas ainda não é aquele que você quer, de cinco mil. Então ela sorri, continua conversando comigo e eu estou submersa, não consigo falar hada. Até que saio dos meus pensamentos, quando ela diz:

Dielle me escuta não tenho muito tempo, pois estão atrás de mim. Testei yma máquina do tempo sem permissão. Mesmo correndo o risco de ser presa ou até morta, escuta bem o que eu vou te falar. Você, em 2020, vai encontrar um namorado, com quem vai se casar e comprar uma casa em 2021. Mas, pelo andar da carruagem, por conta da pandemia, tudo indica que você não vai se casar em 2021 no dia 29 de maio. Ah. Esqueci de te contar da pandemia, que se espalhou pelo mundo inteiro, tipo aqueles filmes que a gente vê, mas as pessoas não se tornaram zumbis. O tempo está acabando Dielle. Não mexe com formatura, que é furada. Você não terá muito dinheiro para tudo isso. A crise está precária, várias pessoas perderam emprego na sua cidade.

Quando eu iria dizer que ela chegou tarde, pois eu já havia assinado o contrato ela desapareceu. Então, minha mãe chegou na cozinha e perguntou om quem estava conversando e me mandou dormir. 


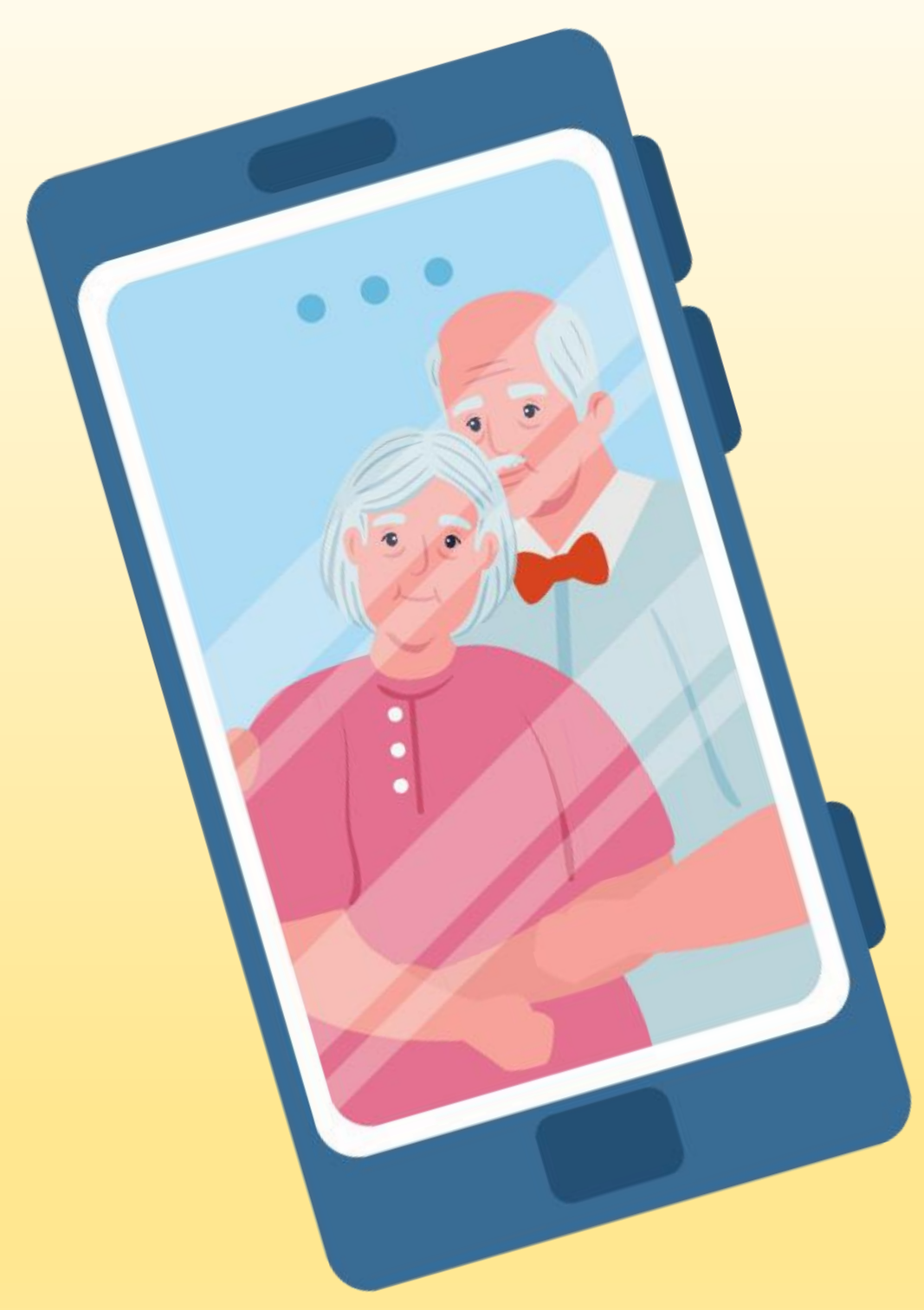

Daiane. Oi, sou você em 2020. Não se assuste, fique calma, não é um sonho. Bom, venho até você para lhe contar um pouco do futuro... Primeiro, você constituirá uma bela família. Irá morar em uma bela fazenda, que será de vocês mesmos. Perto de você irá morar seus pais e sogros, viverá neste ambiente familiar bem feliz e trabalhará na sua terra. Em 2020, iniciará um curso acadêmico de Pedagogia. Porém, antes de te falar de 2020 preciso te falar de 2019 onde muita coisa mudou. Senta um pouquinho. Na verdade, em 2013 você terá a alegria de ter o terceiro filho, que será um menino. No entanto, neste mesmo ano, sua mãe descobre uma terrível doença, com a qual ela luta contra durante 6 anos. Então, infelizmente, em 2019 ela parte para o céu deixando um enorme vazio e imensa tristeza. Seu pai irá ficar desorientado e você e filhos irão sofrer muito. Neste mesmo ano, surge também um vírus no mundo que mudará a vida de todos. A proporção será tão grande, ao ponto de gerar uma Pandemia, parando escolas, comércios e etc. Todos tiveram que se adaptar a uma nova realidade. Por causa deste vírus, muitos também partirão para céu e muitos ficarão sofrendo por seus entes queridos, assim como você por sua mãe. Você está bem, luta todos os dias para vencer as lutas e superar a saudade. Deixo para você hoje a seguinte reflexão. Abrace e ame seus familiares, mãe, vó, pai, primos, amigos como se não houvesse amanhã. Terá amanhã, mas algumas pessoas não estarão lá. Prossiga sempre. Seja sempre assim, uma pessoa de bons sentimentos, honesta e trabalhadora, porque ainda que haja dias difíceis você vencerá juntamente com sua família. Tenha sempre fé. E não desista diante dos obstáculos. 


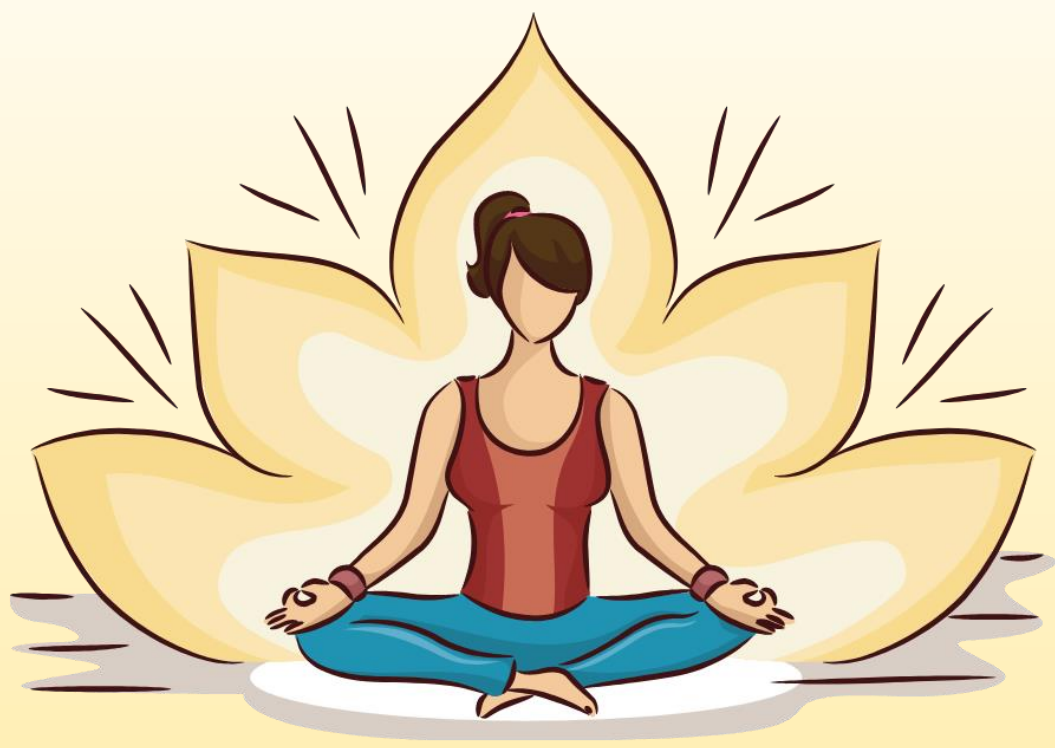

Gabriela Guedes. Oi Gabi. Não assusta, sou você do futuro. Só vim falar com você porque acho melhor estar preparada. Sei que fez mil planos para este ano e sei como estão as suas expectativas. Porém, nesse ano chegará um novo vírus que vai acabar com tudo que planejou. Fique calma. No começo você vai surtar, ficará triste e se sentirá sozinha muitas vezes. Mas, no final, você vai conseguir se adaptar da melhor forma possível e também vai se tornar alguém melhor. E antes que você me pergunte, sua vida amorosa vai ficar de lado esse ano. Você vai focar mais na sua família e na sua faculdade. Use sua garra, sua força e sua fé para te ajudar. Lembre-se sempre que vai dar tudo certo. Continue focando e passando por cima de todos os obstáculos. Tenho muito orgulho de nós eu te amo.

Maenne Marques Moraes. Com a chegada do ano novo, eu estava ansiosa para voltar às aulas, arrumar um emprego, ter uma vida própria aonde eu pudesse correr atrás dos meus sonhos. Infelizmente veio essa pandemia, que dificultou muito as coisas. Mas, mesmo assim, não desisti. Continuei estudando remotamente e tentando arrumar um emprego, que antes estava difícil por ser o primeiro emprego, aí ficou ainda pior. Acabei tendo mais ansiedade do que antes. Todavia foi um ano bom, porque fiquei noiva mesmo nesse tempo. Deus protegeu a mim e à minha família desse mal que está no mundo, e tenho a esperança que tudo vai voltar ao normal. E se não voltar, creio que mesmo assim Deus vai realizar meus sonhos e que tudo vai dar certo, pois quando mais precisei de Deus, Ele estava lá comigo e sou muito grata a Deus por tudo

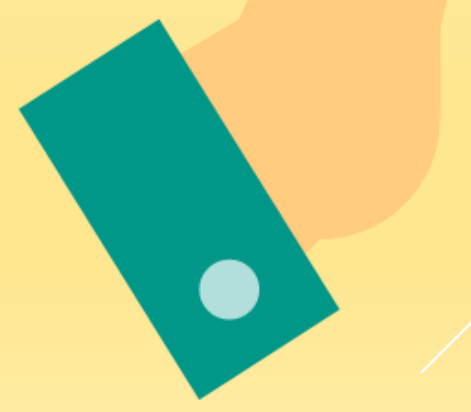

39 


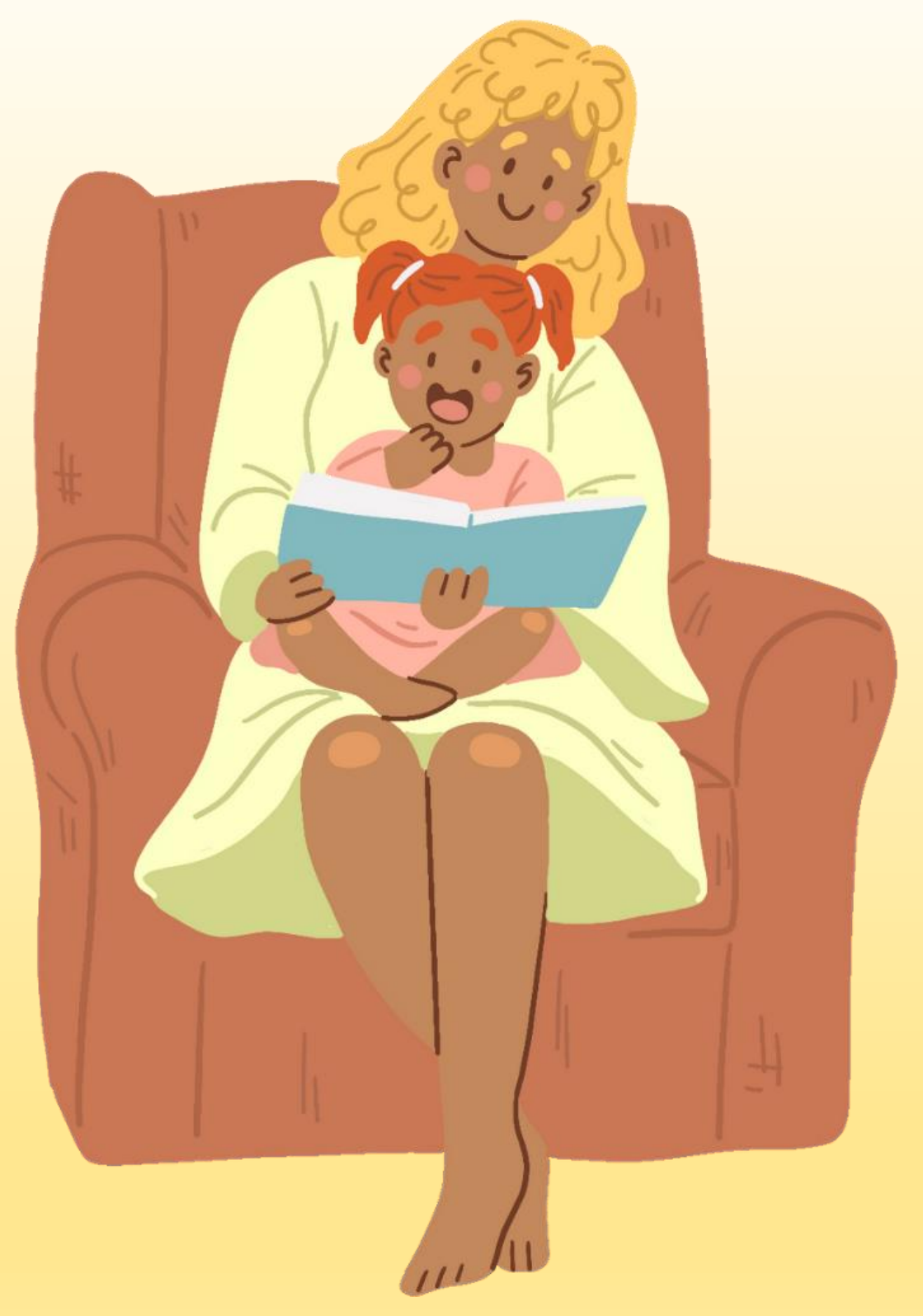

Maricelia Viana da Silva Gomes. Com a chegada do ano de 2020, estava em paz, pois o dia de amanhã só pertence a Deus. Mas quando voltaram as aulas, tive que mudar de horário, saindo do noturno para o integral, pois seria mais fácil conseguir alguém para ficar com minha filha. Comecei assistir as aulas no integral, mas depois não estava mais dando certo. Chegou um momento que tranquei o curso, pois conseguia ir até a faculdade. Logo a coordenadora do curso conversou comigo e resolvi voltar para o noturno, mesmo com tantas dificuldades, sem ter quem ficasse com minha filha. Mas assim que eu ia voltar para as aulas no noturno, aconteceu de suspender as aulas presenciais por causa da pandemia. Por um lado, pra mim foi até melhor, pois eu ia ficar em casa cuidado da minha filha e estudando também. Não está sendo fácil pra ninguém, pois a mudança de rotina foi grande. Pelo menos pra mim, que também precisei auxiliar minha filha todas as tardes; ou melhor, passei a ser a professora da minha filha, que ainda está aprendendo a ler e escrever. Logo em outubro tive um pequeno acidente doméstico, onde trinquei a bacia, mas graças a Deus superei. Já voltei a andar e estou fazendo fisioterapia. Mas Deus está sempre no controle de tudo. 
Jéssica de Souza Oliveira Menezes. Mensagem para 0 meu eu do passado: 2020 chegou e junto dele aquela frase bem clichê de toda virada de ano "ano novo, vida nova". Sonhos, planos, planejamentos, expectativas criadas e principalmente esperança. Mas, de repente, foi tudo por água abaixo. Uma pandemia pegou a maioria das pessoas de surpresa. Hospitais a cada dia mais lotados e famílias de luto. E todos aqueles planos do começo do ano que você planejou e que acabou não sendo o que você esperava? Bom, os planos tiveram que ser outros, ou até mesmo tiveram que ser adiados. Você teve que desacelerar um pouco e ressignificar diversas coisas. Ressignificar! Você ainda vai evoluir muito mais, mas a mudança que ocorreu em você é nítida. Agora você está valorizando mais as pessoas e os momentos, descobrindo novos sentidos, valorizando mais a vida e tendo consciência que nem tudo são flores. Pra tudo tem o momento certo, basta você refletir sobre todas as mudanças e dificuldades e extrair o que você aprendeu nesse tempo.

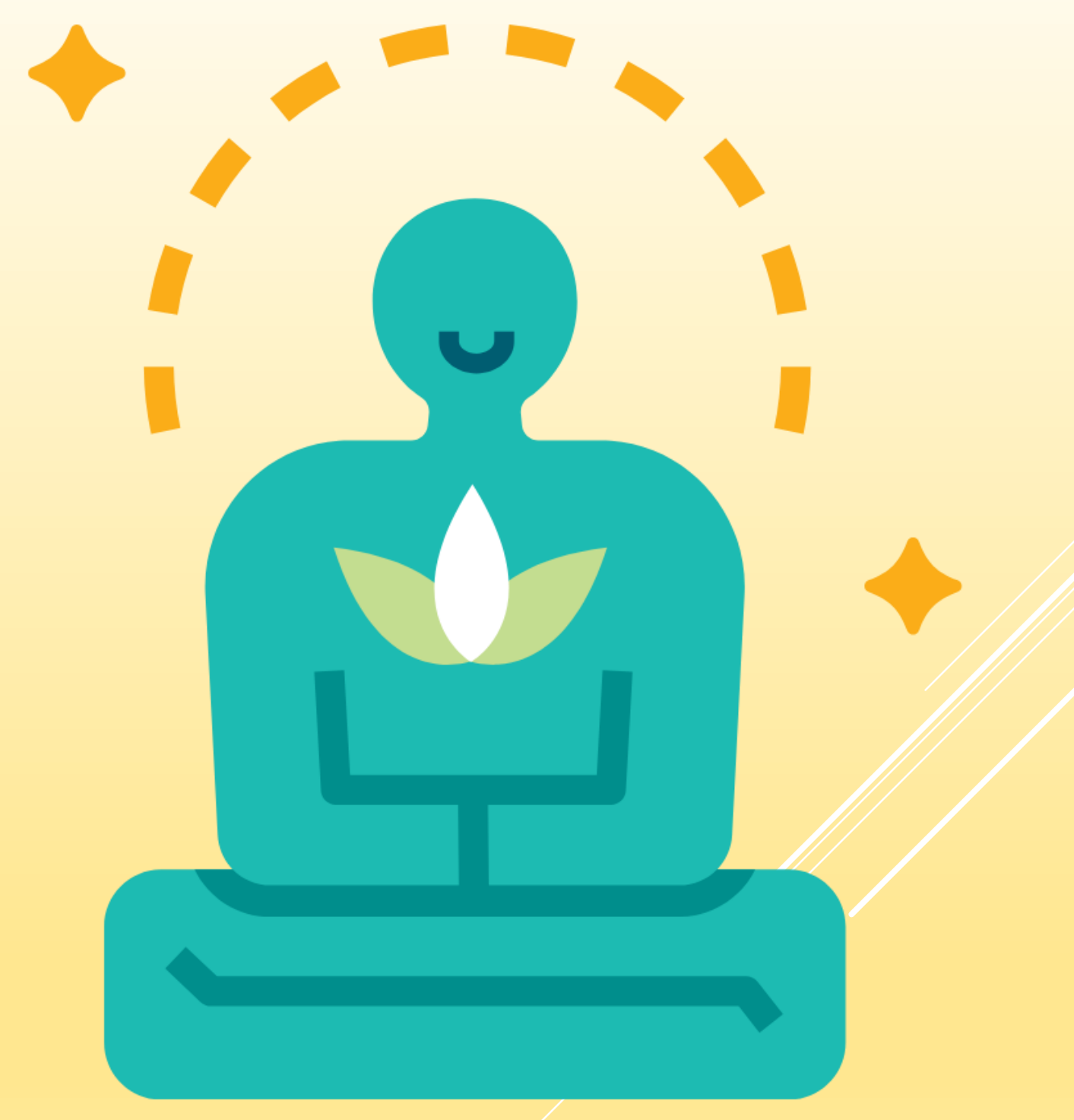




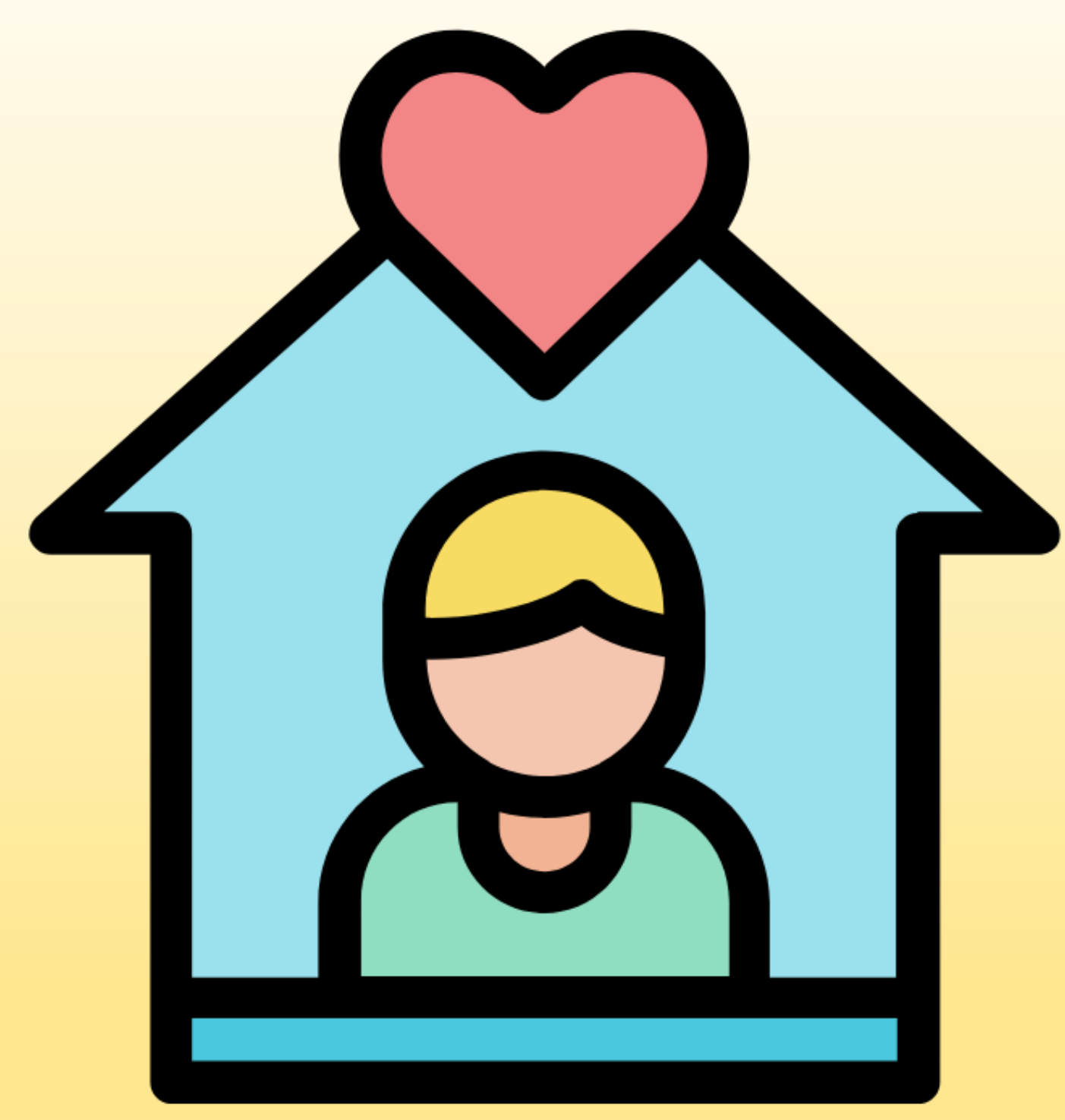

Raquel Gomes de Medeiros Castro. Bom, por onde começar...? Afinal, 2020 foi um ano horrível. Milhares de pessoas estão morrendo devido a pandemia de Covid 19, causada pelo novo coronavírus, que inclusive está mais novo que nunca, visto que são tantas variantes que estão quase invalidando as vacinas que finalmente foram produzidas. Lembra aquele vírus que foi anunciado em dezembro? Pois é. Ele chegou ao Brasil e está fazendo o que quer com a vida do povo brasileiro e de todo o mundo. Mal tem espaços nos cemitérios para os corpos, que não tem nem o direito de ser velados e enterrados com dignidade, que dirá recursos para tratar dos infectados. Agora eles estão morrendo na fila de espera por um leito de UTI e em breve vai ter fila de espera por um leito de enfermaria. Meu recado para você é: se cuide e cuide de quem você ama. Não é hora de visitas e passeios, sair de casa somente se precisar ir ao hospital por urgência e evite coisas que podem te levar a precisar de ir a um hospital. Seus planos foram adiados, surgiram surpresas, algumas agradáveis outras nem tanto. As escolhas tem que ser feitas e por mais necessárias e óbvias que sejam, no final ainda dão um friozinho na barriga e uma certa insegurança. Mas tenha fé em Deus que vai dar tudo certo. Acredite. Aquele ditado que diz que pode não dar tempo de passar o rascunho a limpo é verdade. Viva o hoje com intensidade pois o amanhã a Deus pertence. 
Sabrina Caetano Cardoso. Pela primeira vez, você tinha a plena certeza que seria um ano incrível e cheio de realizações, já que se encontrou na maquiagem e estava super animada. Todos os planos de fazer cursos e conquistar o seu espaço terão que ser adiados. Seja paciente, preste atenção nos detalhes e aprenda a valorizar tudo ao seu redor. A incerteza vai ser gigantesca. Entretanto, nunca deixe que a esperança morra dentro de você, sonhe alto e confie. Ele está no controle de tudo.
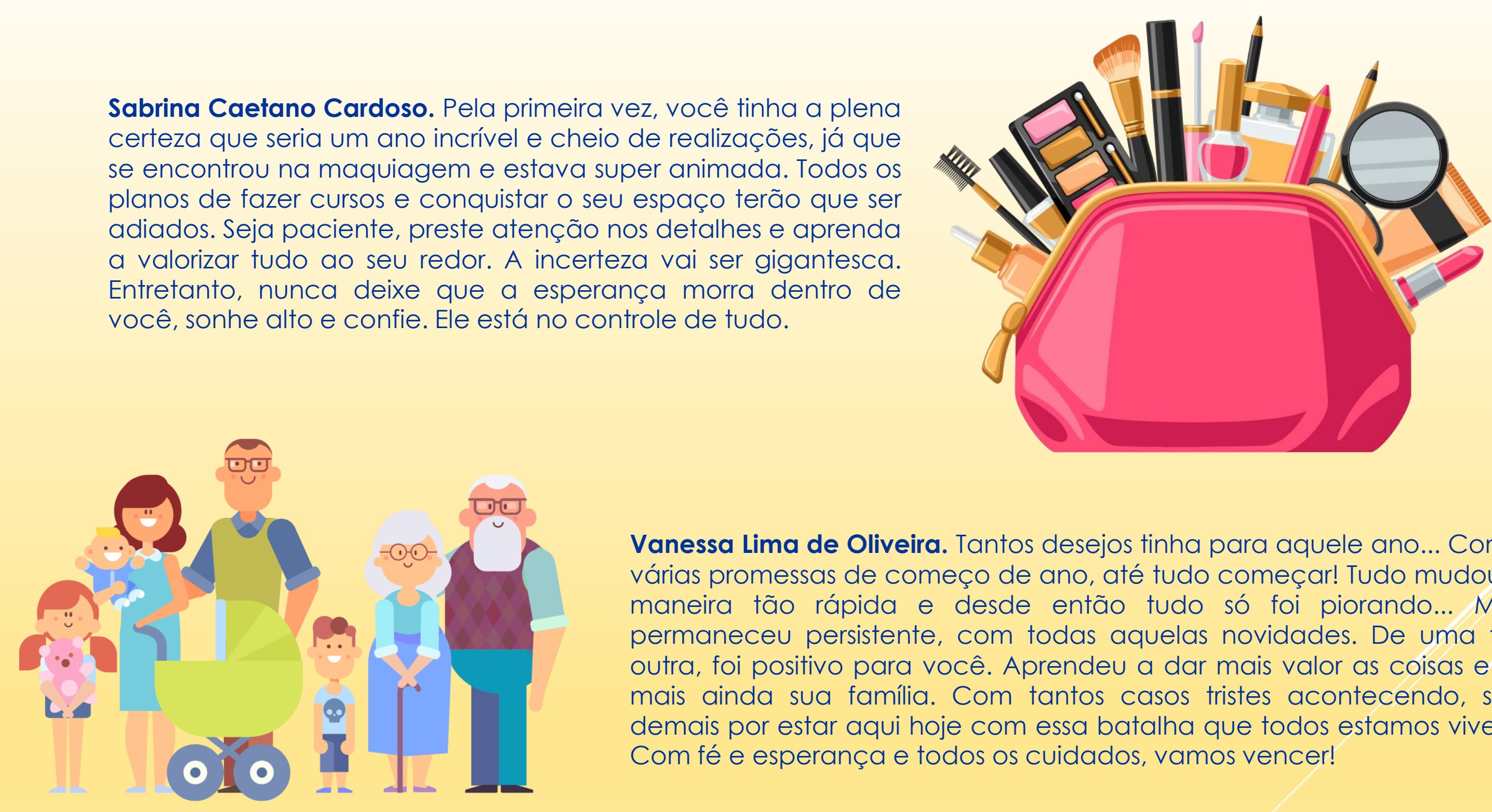

Vanessa Lima de Oliveira. Tantos desejos tinha para aquele ano... Como temos várias promessas de começo de ano, até tudo começar! Tudo mudou de uma maneira tão rápida e desde então tudo só foi piorando... Mas você permaneceu persistente, com todas aquelas novidades. De uma forma ou outra, foi positivo para você. Aprendeu a dar mais valor as coisas e valorizou mais ainda sua família. Com tantos casos tristes acontecendo, sou grata demais por estar aqui hoje com essa batalha que todos estamos vivenciando. Com fé e esperança e todos os cuidados, vamos vencer! 


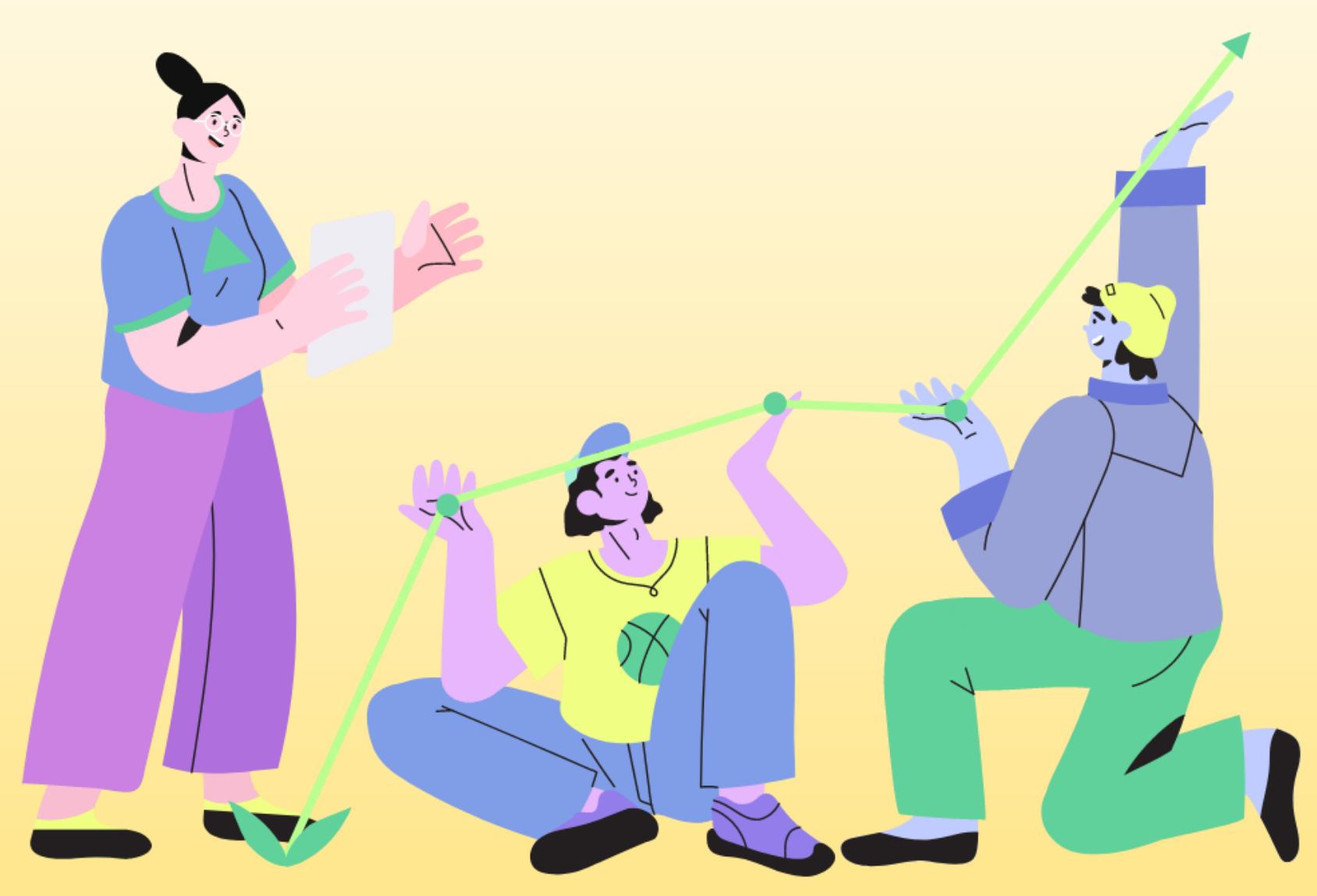

Angélica Ramalho de Freitas Cabral. Mensagem para o meu eu do passado. Mais um ano chegando e como a cada ano que se renova, lá estava ela cheia de planos. Há alguns planos que aos olhos de muitos são até impossíveis de se realizar, expectativas a mil do segundo ano de faculdade. E então chega a inesperada pandemia. Como sempre, Deus nos mostrando que a vontade dele sempre prevalece, que não adianta fazermos mil planos se não for da vontade dele. Um início de ano que mexeu com todos de uma forma inexplicável com muitas dores, sofrimentos e incertezas. Mas, em meio a todo esse caos ela estava aprendendo a dar valor nas pequenas coisas, na família. Em meio a todo esse furacão, Deus realizou aquilo que havia prometido no coração dela, conseguiu também um emprego novo. E agora ela continua, com muita esperança a cada dia que se renova tendo a certeza de que isso tudo irá passar, que juntos vamos vencer essa batalha, e 0 que ficará serão ensinamentos para sermos melhores a cada dia. 


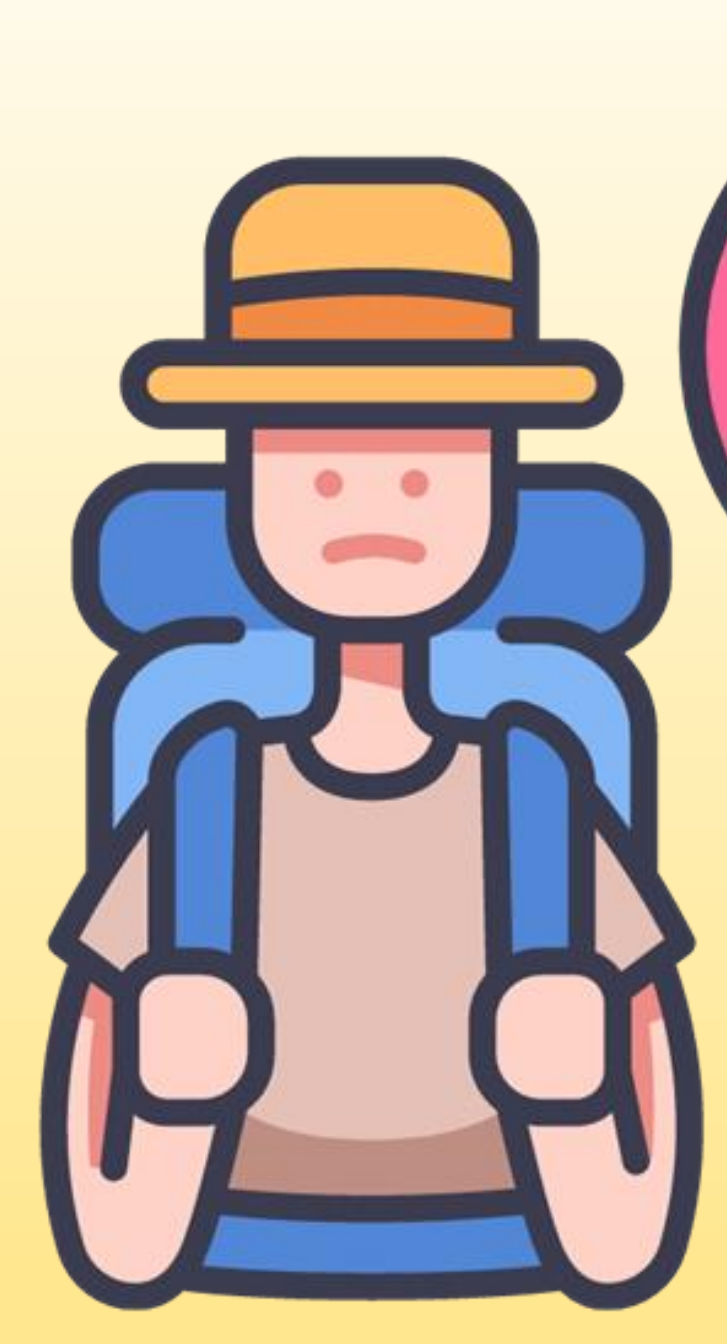

Isabela Rodrigues Silva. Bom, não sei nem por onde começar. Primeiro de tudo calma, ainda não é o fim. E antes que me pergunte, não eu não tenho muitas respostas, nem tampouco soluções. Estou só no terceiro mês do ano e ainda temos nove meses pela frente. Sei que você espera que toda essa loucura de pandemia passe e que volte para sua antiga realidade. Com muito pesar te adianto, nem mesmo que se a pandemia e a Covid deixassem de existir, você não iria voltar a ter o que tinha. Em compensação, você aprenderá que não adianta viver se planejando, se desgastando em prol de um futuro que em poucos dias pode virar de cabeça para baixo. Terá a oportunidade de amadurecer e criar memórias inesquecíveis nesse meio tempo. De eu para eu mesma, não se culpe pelo o que não tem como controlar. E, o mais importante viva o hoje! 


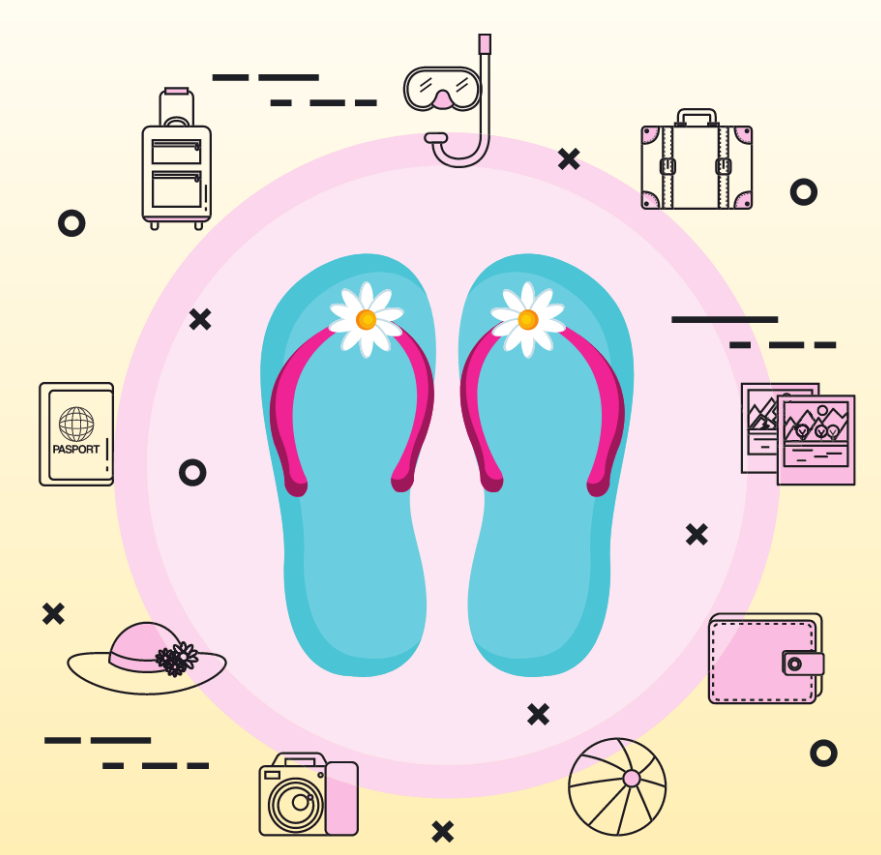

Laura de Oliveira. Bom, não sei como vou te explicar o que está para acontecer nos próximos anos. Mas você precisa entender que vai ter que ser forte. Diante disso, não crie expectativas e aproveite o seu finalzinho de férias, com as pessoas mais próximas do seu ciclo de amigos e familiares, pois você terá perdas que te deixarão cicatrizes para o resto da sua vida. Além de tudo, não perca sua essência e não deixe seus sonhos para trás.

Eshilley Rodrigues Souza. Quando o ano começou, você estava animada com o emprego e tudo o que ele poderia fornecer. Infelizmente, viagens foram canceladas, contatos foram reduzidos, você só viu seu pai duas vezes nesse ano. Mesmo com algumas dificuldades, você consegue chegar no final desse ano, tentando levar a vida da melhor forma possível enquanto se vê desempregada novamente. Apesar de tudo, você conhecerá novas pessoas, que nunca havia imaginado. Mas, acho que a gente continua presa a todas as pessoas do passado. Então, o ano vai ser difícil, mas você consegue passar por ele viva. Não se preocupe demais e tenha mais calma para resolver as situações. Sei que parece impossível, mas também deveria diminuir seu consumo de café, pois ao final do ano ele irá destruir nossa saúde de um jeito peculiar e horrível. Mas é assim. A gente vai saber lidar com tudo o que vier, como sempre.

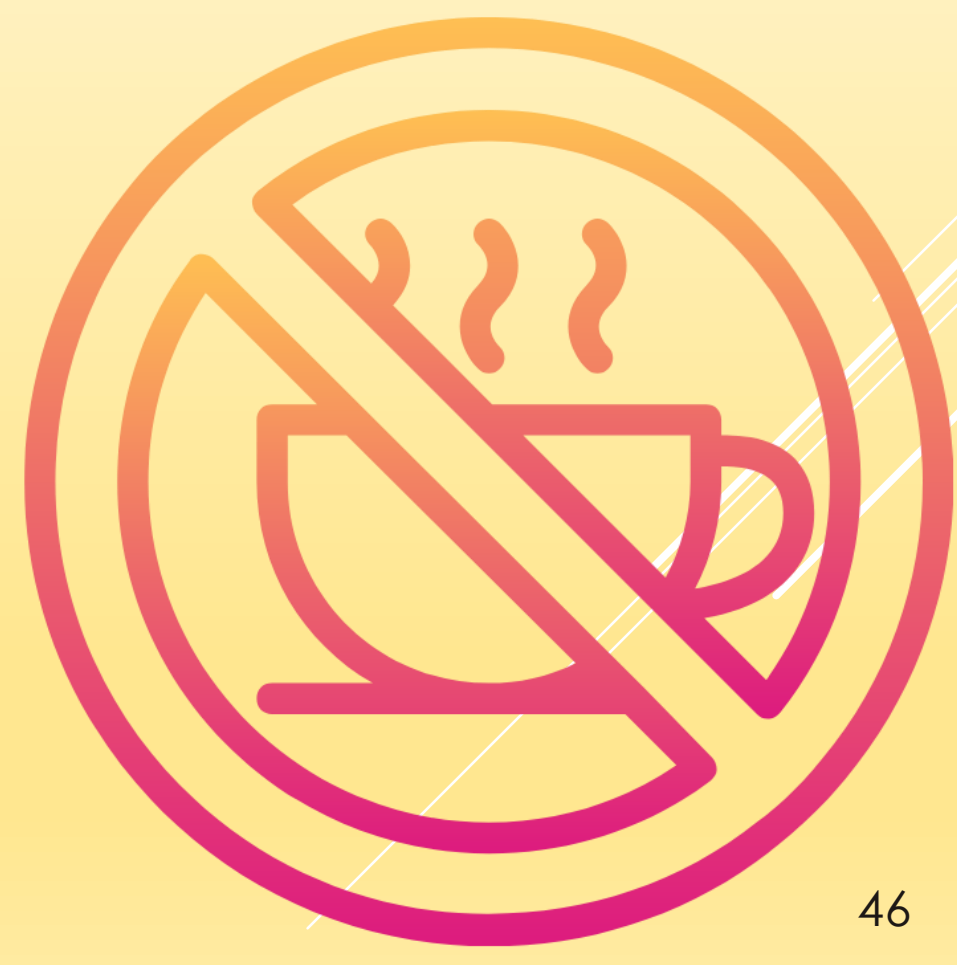




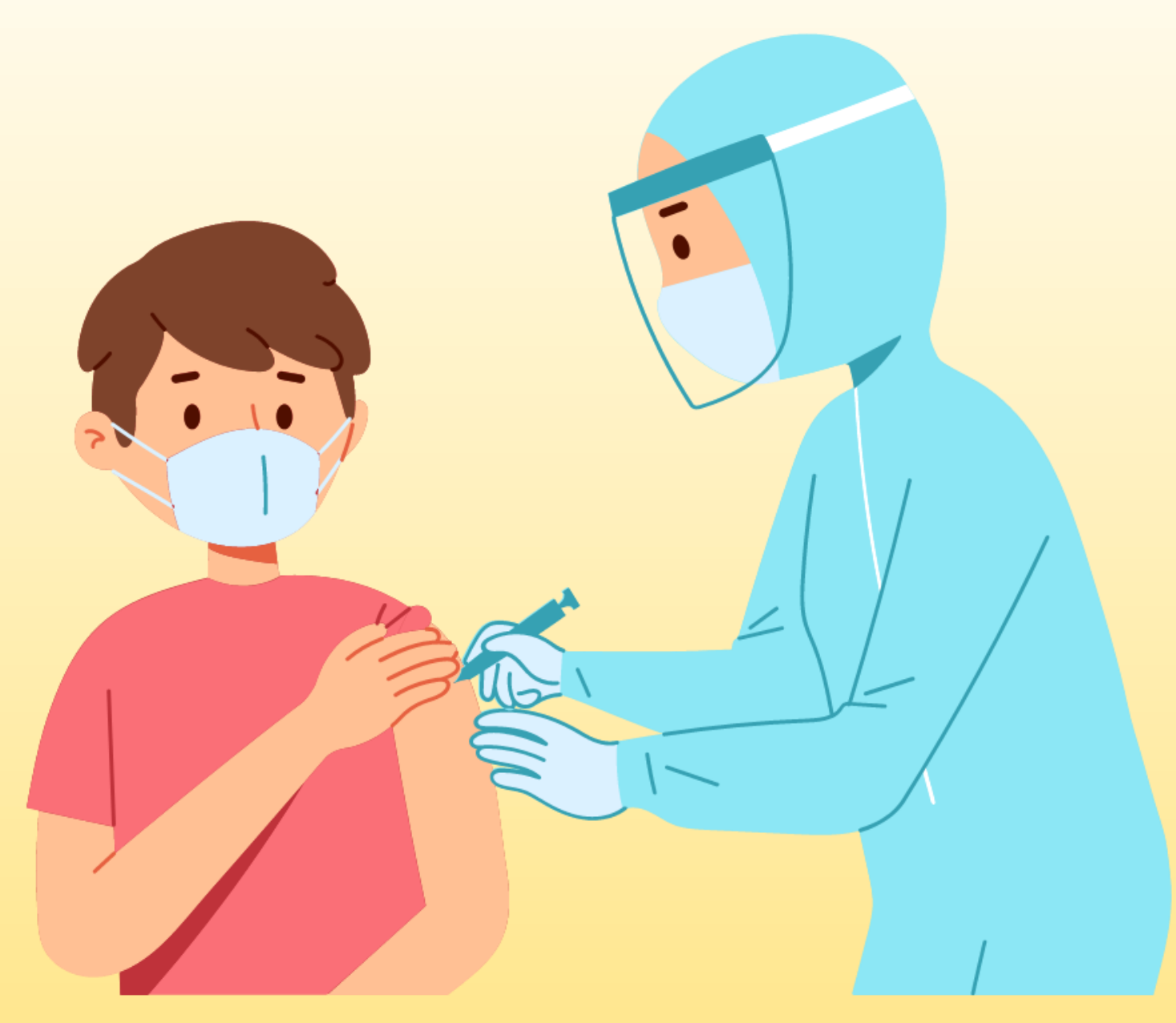

Aline Peixinho. Antes da pandemia pensei em alguns planos para que fossem executados no futuro. Inicialmente, planejei fazer mobilidade nacional em Salvador-Bahia e visitar $o$ meu pai, que reside em Canudos-BA. Logo, eu estaria fazendo mobilidade próxima a cidade dele (faz 7 anos que não abraço o meu pai, mas o futuro nos reserva um encontro cheios de saúde). No ano de 2020, realizei a minha primeira visita à Escola Nacional Florestan Fernandes (Escola de formação política do Movimento dos Trabalhadores Rurais Sem Terra), pois a ENFF é o meu objeto de estudo. Eu tinha planos para retornar à escola, mas com a pandemia não será possível. Nesse momento, estou em casa, realizando as minhas leituras sobre a escola, para que num futuro não tão distante eu possa retornar com conhecimentos e realizar uma troca de saberes. Portanto, o meu único desejo é que todos que estão a minha volta continuem em casa e cheios de saúde para que em outro momento possamos nos reencontrar. Para os próximos dias Vacina e esperança de dias melhores para todos!!! 


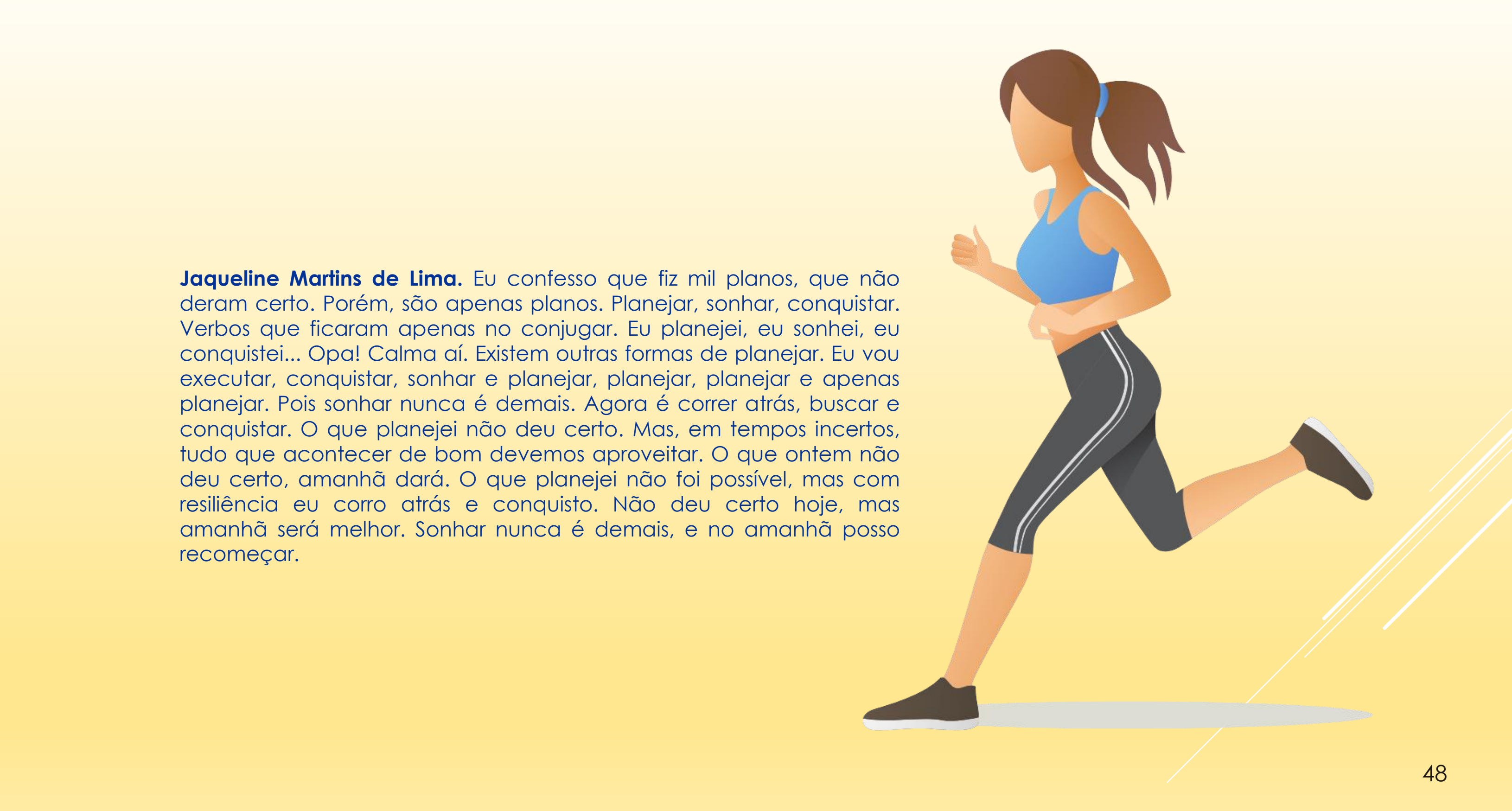


Thaís Martins Padovane. Oi, Thaís. Tudo bem? Sou eu, você. Só que vim do Futuro para tentar te ajudar de certa forma. Não se assuste. Sei que você não vai se assustar, mas preste bem atenção no que eu vou te dizer. Não vai ser um ano fácil, assim como todos os anos que trazem momentos bons e que trazem momentos ruins. Bom, sabe aquela festa em Uberaba? Cancela, não compre o pacote. A viagem? Sim, também cancela. Vai surgir um vírus e esse vírus vai virar o mundo de cabeça pra baixo. No começo você vai achar que vai ser só um mês de quarentena... sim, quarentena, o mundo todo vai ter que mudar sua rotina. Álcool, máscaras, distanciamento e muito cuidado para que não seja contaminado. Esse vírus é danado. Aqui em 2021 ainda estamos travando uma batalha com ele, muitas vidas já foram perdidas. Por falar em vidas perdidas, cuida da sua vó, aquela custosa! Fala pra ela não ir pra lugar algum, muito menos para a igreja. Sim, ela pegou o vírus e você não teve tempo de ver ela, você sequer pensou na possibilidade dela partir. Então, por favor, se puder impedir, impeça. Fala o quanto você a ama. A dor é insuportável. No mais, seja forte, ajude aqueles que perderam o emprego e continue com essa fé e dedicação. Você vai se orgulhar e também vai duvidar da sua força. Vai chorar, passar dias sem dormir. Inventar exercícios em casa. As aulas na faculdade vão parar e depois voltar de forma virtual. Você vai se matricular em poucas disciplinas, e vai dar certo. Vai conseguir uma bolsa na IC e isso vai te ajudar muito psicologicamente. Surreal tudo isso, né? Mas acredite, ainda teve queimada no Pantanal, economia daquele jeito e o presidente? Nada. O presidente Jair, nem máscara usa. Prepara o coração, não vai ser fácil. Beijos!!!!
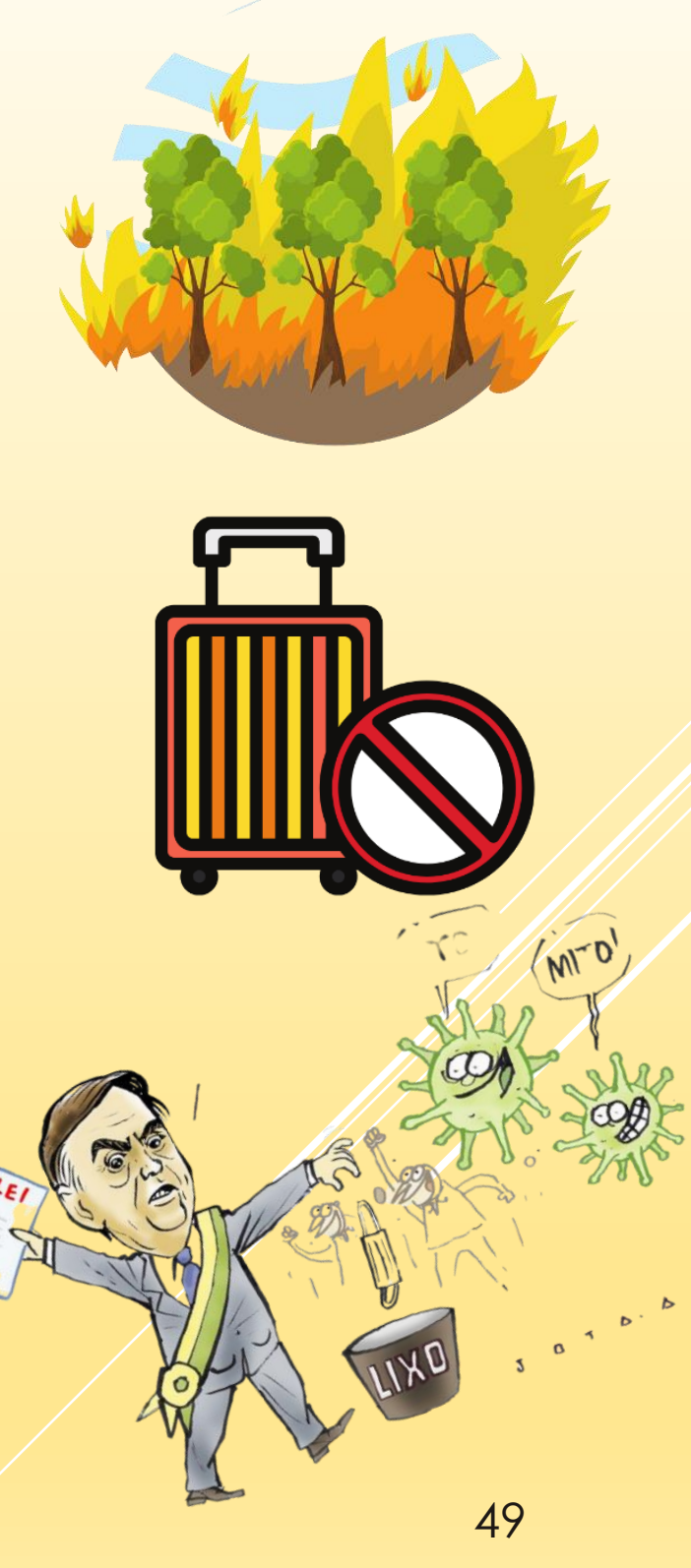

49 


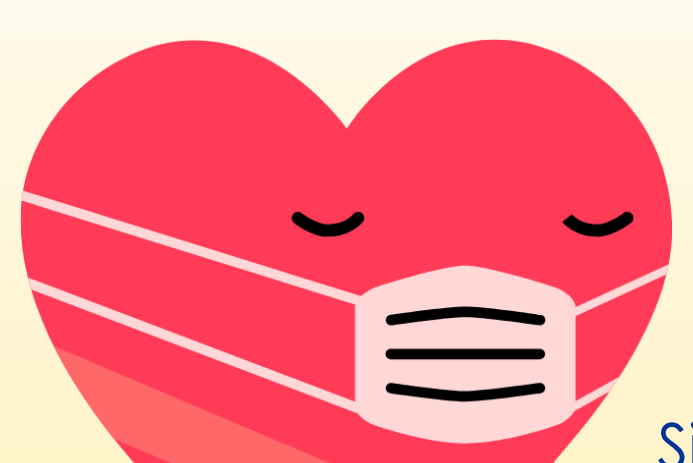

Sinceros agradecimentos a cada um/uma que se abriu para realizar essa atividade. Certamente cada depoimento serve de alerta para a seriedade do momento e, ao mesmo tempo, de aconchego para seguirmos em frente. Superaremos isso e sairemos mais fortalecidos/as. Que venha 2021 com todos os seus desafios.

Prof. ${ }^{a}$ Luciane Dias 
Este livro nasceu de uma atividade

inspirada em um vídeo de Franklin

Medrado. A partir dele, foi só colocar

nossa criatividade em ação.

Conversamos com nós mesmos/as e nos

enviamos vários recadinhos. Entendemos

que, mesmo no sofrimento do momento

pandêmico, podemos colher histórias

que servirão de inspiração para cada um

de nós.

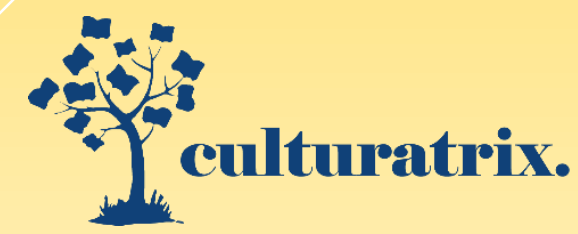

